\title{
ZUSGS
}

science for a changing world

Wildlife Program

Prepared in cooperation with the U.S. Fish and Wildlife Service

Connectivity of Mojave Desert Tortoise Populations: Management Implications for Maintaining a Viable Recovery Network

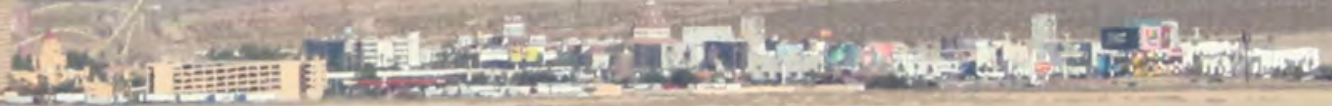

D Open-FiléReport 2021-1033

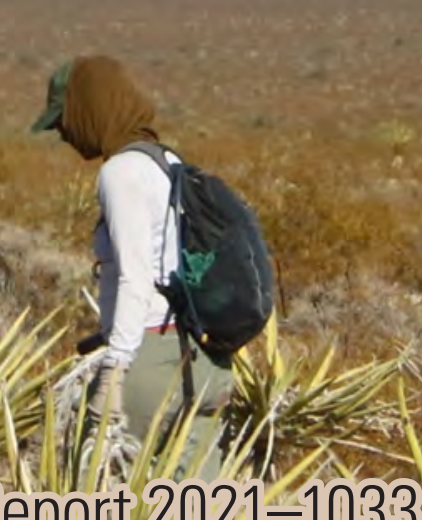
$3{ }^{3} 12$

4. 203 a 20 in in

U.S. Department of the Interior U.S. Geological Survey $\mathrm{V} / \mathrm{d}$
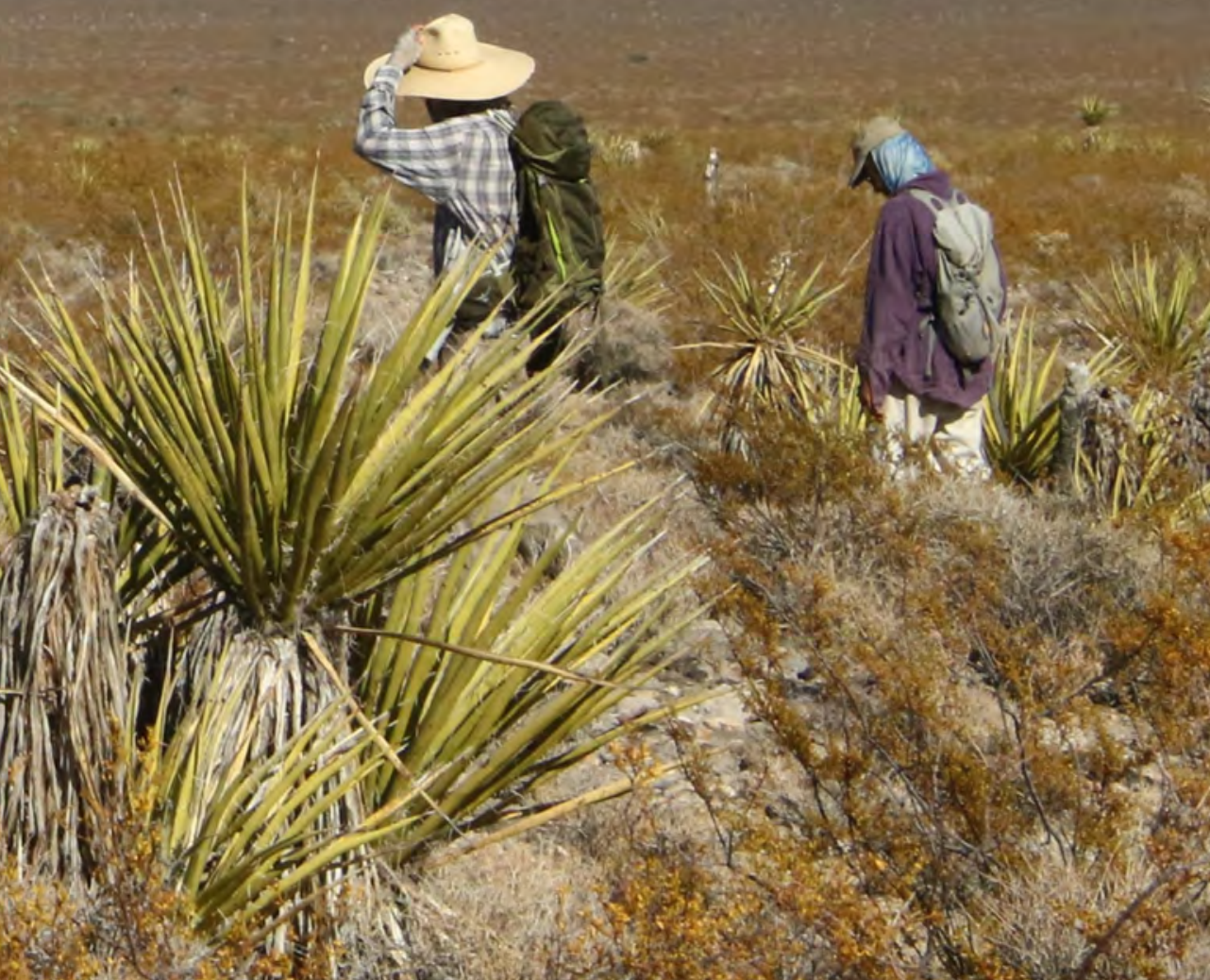
Cover photo: View of field team searching for tortoises in northern Ivanpah Valley, on the border between California and Nevada and central to the Mojave Desert ecoregion. This area is an important habitat connectivity corridor for the Mojave desert tortoise. Photograph by T.C. Esque, U.S. Geological Survey, October 5, 2019. 


\section{Connectivity of Mojave Desert Tortoise Populations: Management Implications for Maintaining a Viable Recovery Network}

By Roy C. Averill-Murray, Todd C. Esque, Linda J. Allison, Scott Bassett, Sarah K. Carter, Kirsten E. Dutcher, Steven J. Hromada, Ken E. Nussear, and Kevin Shoemaker

Wildlife Program

Prepared in cooperation with the U.S. Fish and Wildlife Service

Open-File Report 2021-1033 


\section{U.S. Geological Survey, Reston, Virginia: 2021}

For more information on the USGS - the Federal source for science about the Earth, its natural and living resources, natural hazards, and the environment—visit https://www.usgs.gov or call 1-888-ASK-USGS.

For an overview of USGS information products, including maps, imagery, and publications, visit https://store.usgs.gov/.

Any use of trade, firm, or product names is for descriptive purposes only and does not imply endorsement by the U.S. Government.

Although this information product, for the most part, is in the public domain, it also may contain copyrighted materials as noted in the text. Permission to reproduce copyrighted items must be secured from the copyright owner.

Suggested citation:

Averill-Murray, R.C., Esque, T.C., Allison, L.J., Bassett, S., Carter, S.K., Dutcher, K.E., Hromada, S.J., Nussear, K.E., and Shoemaker, K., 2021, Connectivity of Mojave Desert tortoise populations-Management implications for maintaining a viable recovery network: U.S. Geological Survey Open-File Report 2021-1033, 23 p., https://doi.org/10.3133/ofr20211033.

ISSN 2331-1258 (online) 


\section{Acknowledgments}

Mark Slaughter, Raul Morales, and the Desert Tortoise Management Oversight Group stimulated the development of this white paper and discussion with them helped shape the content. Brett Dickson and Miranda Gray provided advice on the application of the omnidirectional connectivity model. Richard Spotts, Ed LaRue from the Desert Tortoise Council, and Russell Scofield from the Bureau of Land Management in California provided useful comments on the draft. The findings and conclusions in this article are those of the authors and do not necessarily represent the views of the U.S. Fish and Wildlife Service. 



\section{Contents}

Acknowledgments …........................................................................................................................

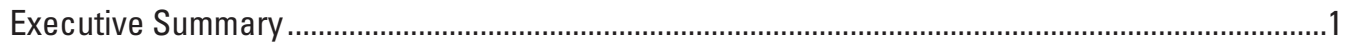

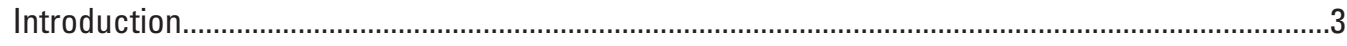

The Framework for Mojave Desert Tortoise Recovery................................................................

Historic Population Connectivity .............................................................................................4

Design and Goals of the Current Network of Tortoise Conservation Areas .............................

Challenges and Weaknesses of the Current Network of Tortoise Conservation Areas ...........4

Functional Connectivity of Desert Tortoise Populations Across the Landscape ........................6

Structure and Dynamics of Desert Tortoise Populations..........................................................

Effectively Connecting Current Desert Tortoise Habitat to Recover Populations.......................8

Recent Research Relevant to Desert Tortoise Habitat and Connectivity.......................................

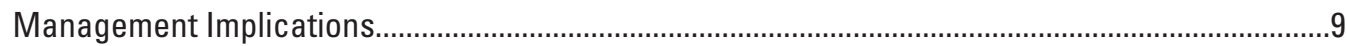

(1) Management of All Desert Tortoise Habitat for Persistence and Connectivity....................9

(2) Limitations on Landscape-level Disturbance Across Habitat Managed for the Desert Tortoise....................................................................................................

(3) Minimization of Mortality from Roads and Maximization of Passage Under Roads..........14

(4) Adaptation of Management Based on New Information ..................................................14

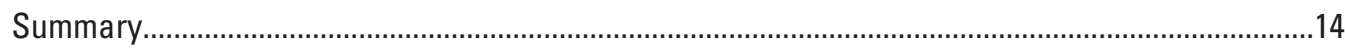

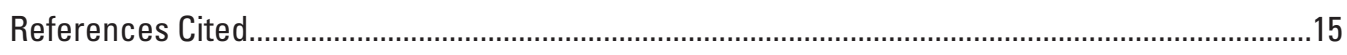

Appendix 1. Recent Desert Tortoise Habitat and Connectivity Models..........................................19

\section{Figures}

1. Map showing population trends and abundance of adult Mojave desert tortoises within tortoise conservation areas ...................................................................

2. Images showing diagrammatic representation of inter-patch habitat connectivity of Mojave desert tortoises ......................................................................

3. Graph showing observations of live Mojave desert tortoises from the U.S. Fish and Wildlife Service range-wide monitoring program relative to the proportion of development in the surrounding landscape within 1 kilometer of the

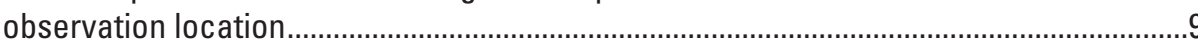

4. Map showing desert tortoise conservation areas and linkages in the California Desert Renewable Energy Conservation Plan .................................................................11

5. Map showing tortoise conservation areas, linkages, and other habitat managed for desert tortoise population connectivity in Nevada, Utah, and Arizona.

\section{Tables}

1. Surface-disturbance caps in desert tortoise conservation areas and linkages in the California Desert Renewable Energy Conservation Plan. 


\section{Conversion Factors}

U.S. customary units to International System of Units

\begin{tabular}{lcl}
\hline \multicolumn{1}{c}{ Multiply } & By & \multicolumn{1}{c}{ To obtain } \\
\hline & Area & \\
\hline acre & 4,047 & square meter $\left(\mathrm{m}^{2}\right)$ \\
acre & 0.4047 & hectare (ha) \\
acre & 0.004047 & square kilometer $\left(\mathrm{km}^{2}\right)$ \\
square mile $\left(\mathrm{mi}^{2}\right)$ & 259.0 & hectare (ha) \\
square mile $\left(\mathrm{mi}^{2}\right)$ & 2.590 & square kilometer $\left(\mathrm{km}^{2}\right)$ \\
mile & 1.609 & kilometer \\
\hline
\end{tabular}

International System of Units to U.S. customary units

\begin{tabular}{lcl}
\hline \multicolumn{1}{c}{ Multiply } & By & \multicolumn{1}{c}{ To obtain } \\
\hline & Area & \\
\hline square meter $\left(\mathrm{m}^{2}\right)$ & 0.0002471 & acre \\
hectare (ha) & 2.471 & acre \\
square kilometer $\left(\mathrm{km}^{2}\right)$ & 247.1 & acre \\
hectare (ha) & 0.003861 & square mile $\left(\mathrm{mi}^{2}\right)$ \\
square kilometer $\left(\mathrm{km}^{2}\right)$ & 0.3861 & square mile $\left(\mathrm{mi}^{2}\right)$ \\
kilometer & 0.6214 & mile \\
\hline
\end{tabular}

\section{Abbreviations}

DRECP Desert Renewable Energy Conservation Plan

TCA tortoise conservation area

USFWS U.S. Fish and Wildlife Service 


\title{
Connectivity of Mojave Desert Tortoise Populations: Management Implications for Maintaining a Viable Recovery Network
}

\author{
By Roy C. Averill-Murray1, Todd C. Esque2, Linda J. Allison1, Scott Bassett3, Sarah K. Carter2, \\ Kirsten E. Dutcher ${ }^{3}$, Steven J. Hromada ${ }^{3}$, Ken E. Nussear ${ }^{3}$, Kevin Shoemaker ${ }^{3}$
}

\section{Executive Summary}

The historic distribution of Mojave desert tortoises (Gopherus agassizii) was relatively continuous across the range, and the importance of tortoise habitat outside of designated tortoise conservation areas (TCAs) to recovery has long been recognized for its contributions to supporting gene flow between TCAs and to minimizing impacts and edge effects within TCAs. However, connectivity of Mojave desert tortoise populations has become a concern because of recent and proposed development of large tracts of desert tortoise habitat that cross, fragment, and surround designated conservation areas. This paper summarizes the underlying concepts and importance of connectivity for Mojave desert tortoise populations by reviewing current information on connectivity and providing information to managers for maintaining or enhancing desert tortoise population connectivity as they consider future proposals for development and management actions.

Maintaining an ecological network for the Mojave desert tortoise, with a system of core habitats (TCAs) connected by linkages, is necessary to support demographically viable populations and long-term gene flow within and between TCAs. There are four points for wildlife and land-management agencies to consider when making decisions that could affect connectivity of Mojave desert tortoise populations (for example, in updating actions in resource management plans or amendments that could help maintain or restore functional connectivity in light of the latest information):

\section{Management of all desert tortoise habitat for} persistence and connectivity. Desert tortoise populations continue to decline within most TCAs, and it is unlikely that trends are better in populations outside protected

\footnotetext{
${ }^{1}$ Desert Tortoise Recovery Office, U.S. Fish and Wildlife Service. 2U.S. Geological Survey.

3 University of Nevada, Reno.
}

areas. Fragmentation exacerbates negative population trends by breaking large continuous populations into smaller isolated populations. Connectivity within large populations can enhance resilience to localized disturbances due to rescue by neighboring individuals. In contrast, smaller fragmented populations are resistant to rescue by their isolation and thus could suffer irreversible declines to extirpation from a variety of threats and stochastic events. Enhanced threat reduction to reverse declines within TCAs and to maintain occupied habitat in the surrounding matrix would help reduce the variability in population growth rates and improve the resilience of protected populations even while implementing efforts to improve connectivity.

Each TCA has unique strengths and weaknesses regarding its ability to support minimum sustainable populations based on areal extent and its ability to support population increases based on landscape connection with adjacent populations. Considering how proposed projects (inside or outside of TCAs) affect connectivity and the ability of TCAs to support at least 5,000 adult tortoises (the numerical goal for each TCA) could help managers to maintain the resilience of TCAs to population declines. The same project, in an alternative location, could have very different impacts on local and regional populations. For example, within the habitat matrix surrounding TCAs, narrowly delineated corridors may not allow for natural population dynamics if they do not accommodate overlapping home ranges along most of their widths so that tortoises reside, grow, find mates, and produce offspring that can replace older tortoises. In addition, most habitat outside TCAs may receive more surface disturbance than habitat within TCAs. Therefore, managing the entire remaining matrix of desert tortoise habitat for permeability may be better than delineating fixed corridors. These concepts apply, especially given uncertainty about long-term condition of habitat, within and outside of TCAs under a changing climate. 
Ultimately, questions such as "What are the critical linkages that need to be protected?" could be better framed as "How can we manage the remaining habitat matrix in ways that sustain ecological processes and habitat suitability for special status species?" Land-management decisions made in the context of the latter question may be more conducive to maintenance of a functional ecological network.

\section{Limitations on landscape-level disturbance across} habitat managed for the desert tortoise. Clearly delineating habitat linkages and differentiating them from non-delineated areas by the uses that are permitted or prohibited within them by specific management guidelines can help achieve functional connectivity. Such guidelines would be most effective if they considered and accounted for all surface disturbances (for example, temporary disturbances such as fiberoptic lines or off-highway vehicle routes, right-of-ways, utility-scale solar development, urbanization) to the extent possible. A weighted framework that varies with the permanence or severity of the disturbance, and can be additive to quantify cumulative effects, could be useful (Xiong, 2020). For example, minor roads can alter tortoise movements independently of other features (Peaden and others, 2017; Hromada and others, 2020), but if the isolated dirt road is accompanied by a powerline that encourages raven predation (Xiong, 2020), then the two features together may be additive. Ignoring minor or temporary disturbance on the landscape could result in a cumulatively large impact that is not explicitly acknowledged (Goble, 2009); therefore, understanding and quantifying all surface disturbance on a given landscape is prudent.

a. In California, the Bureau of Land Management established 0.1-1.0 percent caps on new surface-disturbance for TCAs and mapped linkages that address the issues described in number 1 of this list.

b. Nevada, Utah, and Arizona currently do not have surface-disturbance limits. Limits comparable to those in the Desert Renewable Energy Conservation Plan (DRECP) would be 0.5 percent within TCAs and 1 percent within the linkages modeled by Averill-Murray and others (2013). Limits in some areas of California within the Desert Renewable Energy Conservation Plan, such as Ivanpah Valley, are more restrictive, at 0.1 percent. Continuity across the state line in Nevada could be achieved with comparable limits in the adjacent portion of Ivanpah Valley, as well as the Greater Trout Canyon Translocation Area and the Stump Springs Regional Augmentation Site. These more restrictive limits would help protect remaining habitat in the major interstate connectivity pathway through Ivanpah Valley and focal areas of population augmentation that provide additional population connectivity along the western flank of the Spring Mountains.

c. In a recent study that analyzed 13 years of desert tortoise monitoring data, nearly all desert tortoise observations were at sites in which 5 percent or less of the surrounding landscape within 1 kilometer was disturbed (Carter and others, 2020a). To help maintain tortoise habitability and permeability across all other non-conservation-designated tortoise habitat, all surface disturbance could be limited to less than 5-percent development per square kilometer because the 5-percent threshold for development is the point at which tortoise occupation drops precipitously (Carter and others, 2020a). However, although individual desert tortoises were observed at development levels up to 5 percent, we do not know the fitness or reproductive characteristics of these individuals. This level of development also may not allow for long-term persistence of healthy populations that are of adequate size needed for demographic or functional connectivity; therefore, a conservative interpretation suggests that, ideally, development could be lower. Lower development levels would be particularly useful in areas within the upper 5 th percentile of connectivity values modeled by Gray and others (2019).

d. Reducing ancillary threats in places where connectivity is restricted to narrow strips of habitat, for example, narrow mountain passes or vegetated strips between solar development, could enhance the functionality of these vulnerable linkages. In such areas, maintaining multiple, redundant linkages could further enhance overall connectivity.

\section{Minimization of mortality from roads and} maximization of passage under roads. Roads pose a significant threat to the long-term persistence of local tortoise populations, and roads of high traffic volume lead to severe population declines, which ultimately fragments populations farther away from the roads. Three points (a.-c.) pertain to reducing direct mortality of tortoises on the many paved roads that cross desert tortoise habitat and to maintaining a minimal level of permeability across these roads:

a. Tortoise-exclusion fencing tied into culverts, underpasses, overpasses, or other passages below roads in desert tortoise habitat, would limit vehicular mortality of tortoises and provide opportunities for movement across the roads. Installation of shade structures on the habitat side of fences installed in areas with narrow population-depletion zones would limit overheating of tortoises that may pace the fence. 
b. Passages below highways could be maintained or retrofitted to ensure safe tortoise access, for example, by filling eroded drop-offs or modifying erosion-control features such as rip-rap to make them safer and more passable for tortoises. Wildlife management agencies could work with transportation departments to develop construction standards that are consistent with hydrologic/erosion management goals, while also incorporating a design and materials consistent with tortoise survival and passage and make the standards widely available. The process would be most effective if the status of passages was regularly monitored and built into management plans.

c. Healthy tortoise populations along fenced highways could be supported by ensuring that land inside tortoise-exclusion fences is not so degraded that it leads to degradation of tortoise habitat outside the exclusion areas. For example, severe invasive plant infestations inside a highway exclusion could cause an increase of invasive plants outside the exclusion area and degrade habitat; therefore, invasive plants inside road rights of way could be mown or treated with herbicide to limit their spread into adjacent tortoise habitat and minimize the risk of these plants carrying wildfires into adjacent habitat.

\section{Adaptation of management based on new information.}

Future research will continue to build upon and refine models related to desert tortoise population connectivity and develop new ones. New models could consider landscape levels of development and be constructed such that they share common foundations to support future synthesis efforts. If model development was undertaken in partnership with entities that are responsible for management of desert tortoise habitat, it would facilitate incorporation of current and future modeling results into their land management decisions. There are specific topics that may be clarified with further evaluation:

a. The effects of climate change on desert tortoise habitat, distribution, and population connectivity;

b. The effects of large-scale fires, especially within repeatedly burned habitat, on desert tortoise distribution and population connectivity;

c. The ability of solar energy facilities or similar developments to support tortoise movement and presence by leaving washes intact; leaving native vegetation intact whenever possible, or if not possible, mowing the site, allowing vegetation to re-sprout, and managing weeds; and allowing tortoises to occupy the sites; and

d. The design and frequency of underpasses necessary to maintain functional demographic and genetic connectivity across linear features, like highways.

\section{Introduction}

Connectivity of Mojave desert tortoise (Gopherus agassizii) populations has become an issue of increasing concern due to recent and proposed development of large tracts of desert tortoise habitat that cross, fragment, and surround designated conservation areas. Much of this development is a result of the recent renewable energy boom, but also includes long-planned urban expansion and infrastructure projects that are reaching the implementation phase. Researchers have studied the implications of existing tortoise conservation areas becoming isolated due to this development and have modeled past, current, and potential future population connectivity across the desert tortoise's range (see later in the text). Managers have incorporated much of the available information into individual planning decisions (for example, Desert Renewable Energy and Conversation Plan Land Use Plan Amendment to the California Desert Conservation Plan of 1980 [DRECP], draft Apple Valley Habitat Conservation Plan). However, general principles for maintaining functionally connected desert tortoise populations have not been synthesized to assist with a comprehensive, species-wide analysis, and several existing land-management plans lack the focus on desert tortoise population connectivity present in other plans such as the DRECP. The Management Oversight Group for the Mojave Desert Tortoise requested guidance to clarify the needs of the Mojave desert tortoise for habitat connectivity from the Western Ecological Research Center of the U.S. Geological Survey and the Recovery Office of the U.S. Fish and Wildlife Service for the Mojave Desert Tortoise. This report is a collaboration to provide that guidance by summarizing the underlying concepts and importance of connectivity for Mojave desert tortoise populations by (1) reviewing current information on connectivity and (2) providing information to managers for maintaining or enhancing desert tortoise population connectivity as they consider future proposals for development and management actions. 


\section{The Framework for Mojave Desert Tortoise Recovery}

\section{Historic Population Connectivity}

The historic distribution of Mojave desert tortoises was relatively continuous across the range, broken only by major topographic barriers, such as the Baker Sink and Death Valley, California, and the Spring Mountains, Nevada (Germano and others, 1994; Nussear and others, 2009, respectively). Although desert tortoises generally do not move long distances over their lifetimes, historically, modest dispersal and connected home ranges occurred over a relatively continuous distribution across the tortoise's range. This contiguous distribution fostered historically high levels of gene flow and a population structure characterized as isolation-by-distance (Murphy and others, 2007; Hagerty and Tracy, 2010; Hagerty and others, 2011). Maintaining functionally connected landscapes is necessary to conserve historic genetic gradation (Frankham, 2006). Large, connected landscapes also are necessary to facilitate natural range shifts in response to climate change (Krosby and others, 2010; National Fish, Wildlife, and Plants Climate Adaptation Partnership, 2012; Hilty and others, 2020). Nevertheless, though gene flow and adaptive capacity are critically important in the long term, the need for extensive, unfragmented habitat is of more immediate concern for supporting populations that are demographically viable on time scales relative to management (Kuo and Janzen, 2004).

\section{Design and Goals of the Current Network of Tortoise Conservation Areas}

Tortoise conservation areas $\left(\mathrm{TCAs}^{1}\right)$ form the foundation of the desert tortoise recovery strategy and are centered around 12 designated critical habitat units that range in area from approximately 220 to 4,131 square miles (U.S. Fish and Wildlife Service, 2011). Effective conservation areas are designed to support species viability according to ecological concepts of representation, redundancy, and resilience (U.S. Fish and Wildlife Service, 1994, 2016; Shaffer and Stein, 2000).

- Representation captures the breadth of genetic or ecological diversity of a species, and recovery units

\footnotetext{
${ }^{1}$ Tortoise conservation areas include desert tortoise habitat within designated critical habitat, Desert Wildlife Management Areas, Areas of Critical Environmental Concern, Grand Canyon-Parashant National Monument, Desert National Wildlife Refuge, National Park Service lands, Red Cliffs Desert Reserve, and other conservation areas or easements managed for desert tortoises (U.S. Fish and Wildlife, 2011).
}

are distributed across the range in a pattern designed to capture this breadth (U.S. Fish and Wildlife Service, 2011).

- Redundancy, having multiple protected populations within representative units, protects against catastrophic loss of any particular population. In the case of the Mojave desert tortoise, each of the recovery units identified in the 2011 recovery plan contain multiple TCAs, except for the Upper Virgin River Recovery Unit in Utah (U.S. Fish and Wildlife Service, 2011).

- Resilience represents the ability of populations to recover from stochastic setbacks, such as drought-induced population declines or localized disease outbreaks. To maintain resilience, TCAs were envisioned to sustain a population of at least 5,000 adult tortoises (U.S. Fish and Wildlife Service, 1994). In situations where a critical habitat unit was smaller than the threshold of 1,295 square kilometers $\left(\mathrm{km}^{2}\right)$, or if the number of tortoises was found to be fewer than 5,000, land management was expected to maintain connectivity to larger populations outside the critical habitat unit and to other critical habitat units (U.S. Fish and Wildlife Service, 1994).

The importance of tortoise habitat outside of TCAs, to recovery, has long been recognized for its contributions to supporting gene flow among TCAs and to minimizing impacts and edge effects within TCAs (U.S. Fish and Wildlife Service, 1994, 2011). This dependence, on a reserve design of protected areas supported by surrounding areas that are not necessarily protected, is considered the linchpin of sustaining a resilient protected area network (U.S. Fish and Wildlife Service, 2011).

\section{Challenges and Weaknesses of the Current Network of Tortoise Conservation Areas}

When the original recovery plan was developed, there were no reliable abundance estimates for tortoises in any critical habitat unit. However, one unit in particular, the Upper Virgin River Critical Habitat Unit, was insufficient in size to support the necessary 5,000 adult tortoises, thus, it was identified as requiring intensive management since its establishment (U.S. Fish and Wildlife Service, 1994). Range-wide monitoring since 2004 (1999 in Upper Virgin River) provides population estimates and recent changes in tortoise density for each TCA. As of 2014, 11 of 17 TCAs had negative population trends, and 8 of 17 were estimated to contain fewer than 5,000 adult tortoises (Allison and McLuckie, 2018; fig. 1). 


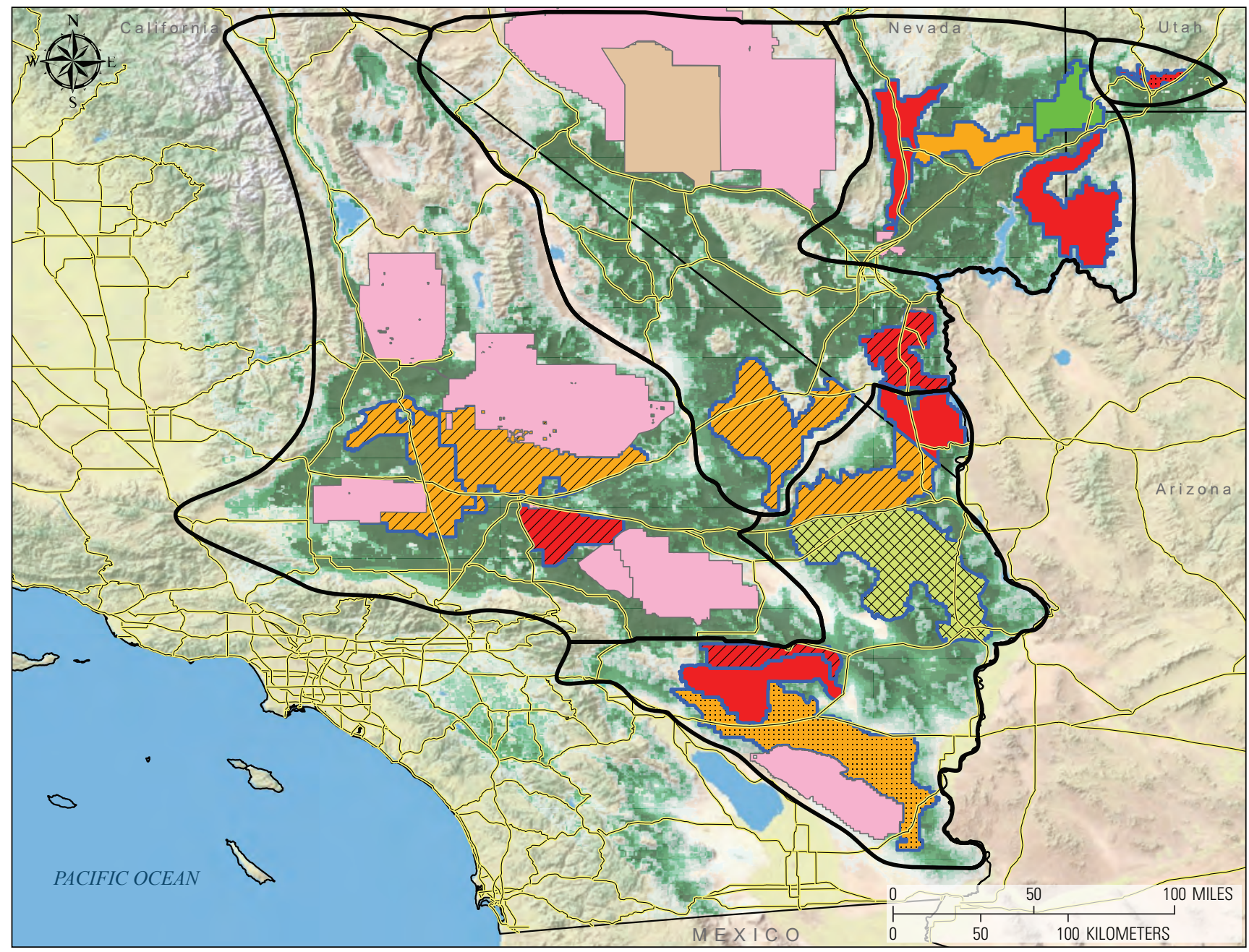

Image source: National Geographic Society. Copyright:@ 2013 National Geographic Society, i-cubed.

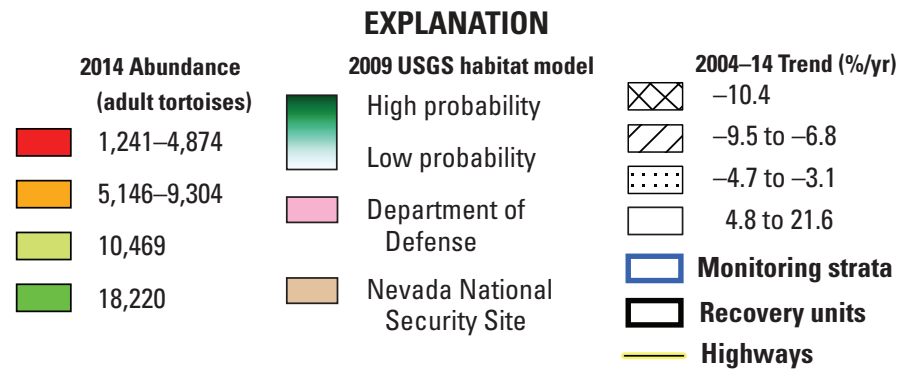

Figure 1. Population trends and abundance of adult Mojave desert tortoises within tortoise conservation areas (TCAs). Yellow lines represent major roads and highways. Color ramp from white to green represents low to high probability of tortoise presence, respectively. 
In addition to concerns about the status of tortoise populations within the TCAs, the configuration of several TCAs is inconsistent with optimal reserve design. The theoretically optimal reserve shape would be circular to minimize the perimeter and potential edge effects relative to the area because the quality of habitat within conservation areas can be affected by factors present outside conservation area boundaries (Harrison and Bruna, 1999; Environmental Law Institute, 2003; Radeloff and others, 2010). For example, subsidized predators within the urban-wildland interface can affect tortoise populations well within TCAs (Kristan and Boarman, 2003; Esque and others, 2010). However, to capture the actual pattern of suitable habitat while accommodating land ownership considerations, all TCAs have complex perimeters, often with narrow extensions or projections into relatively unprotected habitat (fig. 1). This is partly because, prior to TCA establishment, the landscape already had many inholdings and disturbances that were avoided because they rendered the habitat incompatible for tortoise use. The result of this configuration is a network of land parcels of variable habitat quality and tortoise permeability (Gray and others, 2019). All of these issues emphasize the importance of maintaining, and ideally increasing, the availability of habitat connectivity within and among TCAs.

\section{Functional Connectivity of Desert Tortoise Populations Across the Landscape}

Connectivity can be viewed as the degree to which regional landscapes, encompassing a variety of natural, semi-natural, and developed land-cover types, are conducive to wildlife movement and to sustaining ecological processes (Ament and others, 2014; Hilty and others, 2020).

Functionally, connectivity describes the degree to which landscapes facilitate or impede the movement of organisms and processes (Meiklejohn and others, 2010; Hilty and others, 2020). Decreased connectivity results from various degrees of landscape resistance. For example, natural linear features that entirely preclude movement for tortoises include impassable vertical cliffs, talus slopes, and large rivers. Semi-permeable features include natural habitats with questionably sufficient thermal cover, such as burned areas or playa edges, or other features typical of the urban-wildland interface, such as ploughed lots, roads, railways, and large berms, all of which can act as filters that reduce connectivity between populations in the absence of appropriate underpasses or overpasses (Peaden and others, 2015; Rautsaw and others, 2018; Dutcher and others, 2020a; Hromada and others, 2020).

The features listed in the previous paragraph are widespread across the Mojave Desert; for example, almost all TCAs are divided internally or separated from adjacent units by major roads and highways (fig. 1). Abundance of tortoise sign decreases closer to unfenced roadways, resulting in a zone of population depletion of up to 4 kilometers $(\mathrm{km})$ from highways with the highest traffic volumes (Hoff and Marlow, 2002; Boarman and Sazaki, 2006; Nafus and others, 2013; Peaden and others, 2015). These depleted zones effectively eliminate or severely reduce connectivity of tortoise populations across the range. Many miles of tortoise-barrier fencing have been installed along roads, primarily within TCAs, with this fencing connected to culverts. Although individual tortoises cross through culverts (Boarman and others, 1998; Hromada and others, 2020), the effectiveness of culverts in mitigating the fragmenting effects of highways at a population scale is unknown. Even culverts designed to reduce resistance across linear barriers can be ineffective if materials such as rip-rap of talus-sized rocks prevent access by tortoises.

\section{Structure and Dynamics of Desert Tortoise Populations}

Desert tortoises do not occur at uniform densities across the landscape (Krzysik, 2002). Local population abundances fluctuate asynchronously because of differences in habitat quality and variability in precipitation patterns, such as localized declines attributed to drought, disease, or predation events (Peterson, 1994; Longshore and others, 2003; Tracy and others, 2004; Esque and others, 2010; Emblidge and others, 2015) or stochastic population dynamics (U.S. Fish and Wildlife Service, 2011). Adjacent habitat patches of sufficient quality to support healthy tortoise populations are necessary for local population declines or extinctions to be rescued by recolonization (Fahrig and Merriam, 1994). As habitat is lost and fragmented, habitat patches become smaller, patch populations (for example, clusters of tortoises) have fewer tortoises and become more disjunct, extinction probabilities within patches increase, and the number of occupied patches decreases (Fahrig, 2002; Ovaskainen and others, 2002). As described earlier, tortoise populations adjacent to and contiguous with populations within TCAs are essential for long-term species viability and recovery given the limitations of the existing TCA reserve design (fig. 2). 


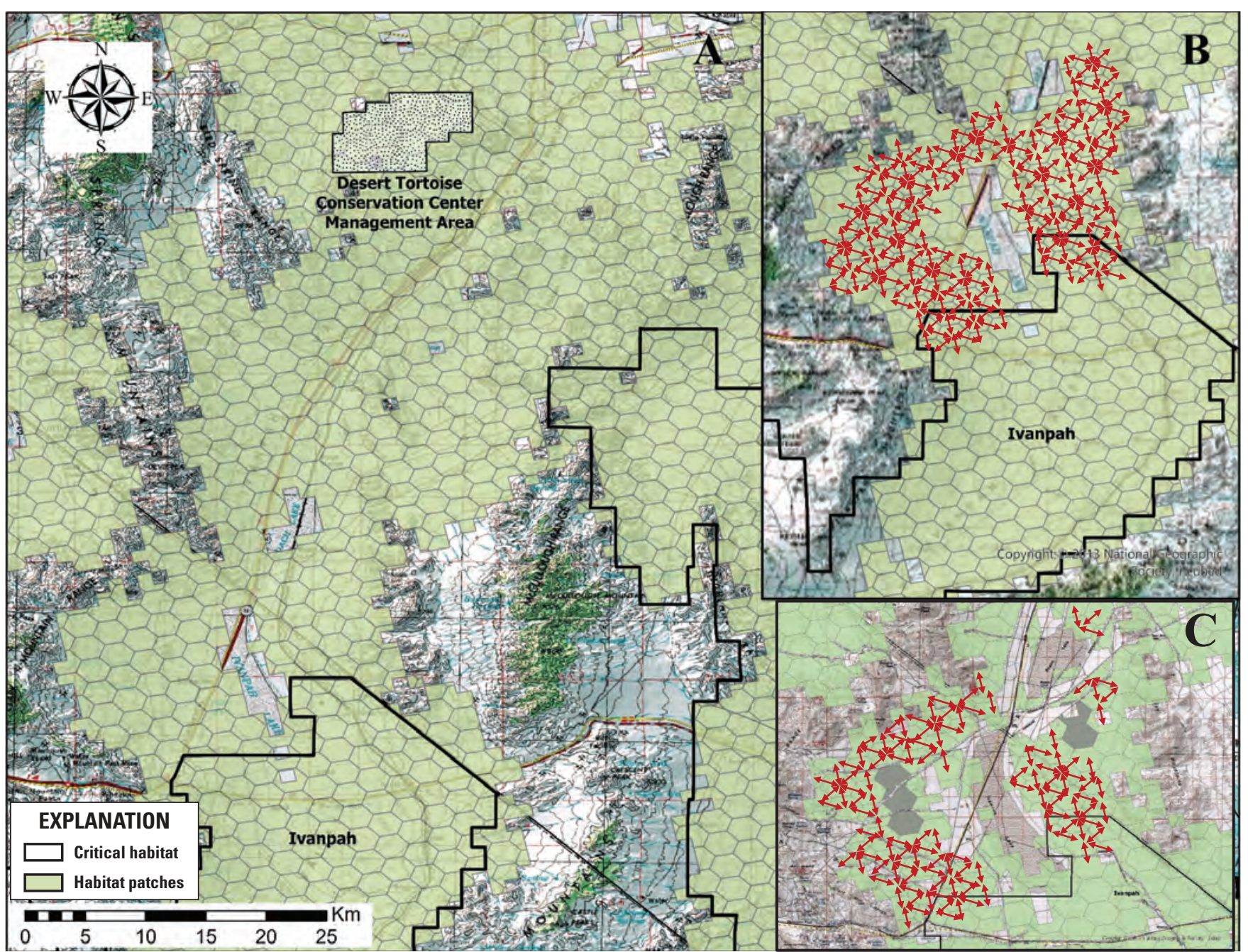

Image source: National Geographic Society. Copyright:@ 2013 National Geographic Society, i-cubed.

Figure 2. Inter-patch habitat connectivity of Mojave desert tortoises. Each hexagon represents a 259-hectare (640-acre) habitat patch. $A$, Historically interconnected habitat constrained by major topographic barriers; $B$, Inter-patch relationships across a part of the landscape are represented by red arrows; and $C$, Reduction in patch connections occurs with habitat loss and fragmentation, conceptually represented by gray patches. 
Large expanses of high-quality habitat are necessary to increase the likelihood that tortoises from local areas, with higher recruitment, will emigrate and repopulate (or "rescue") adjacent areas of suitable habitat (for example, within TCAs) that may have fewer tortoises due to low recruitment or high mortality (Germano and Joyner, 1988; Morafka, 1994; Tracy and others, 2004). This rescue effect has been described and studied using island biogeography concepts and principles that lead us to expect that the probability a population will persist is related to the size and isolation of the habitat patch on which it exists (MacArthur and Wilson, 1967; Brown and Kodric-Brown, 1977). Figure $2 B$ provides an example of the historical relationship between habitat patches for desert tortoises in the Mojave Desert. Patches suffering localized declines in tortoise numbers could be recolonized by tortoises emigrating from adjacent patches. As habitat is degraded, lost, or fragmented by anthropogenic barriers, however, inter-patch relationships may break down, resulting in a decreased likelihood that recolonizations will occur. In short, tortoises within remaining patches that have fewer connections are more likely to be extirpated and less likely to be replaced than tortoises inhabiting patches surrounded by permeable habitats with intact connections (fig. 2C; Lefkovitch and Fahrig, 1985). Such fragmentation could isolate and reduce the viability of regional populations, including those within TCAs, creating an "extinction debt" (Kuussaari and others, 2009; Hylander and Ehrlén, 2013) that extends well beyond the perimeters of parcels of lost habitats. Rescue of unoccupied habitat patches may not occur, or may be delayed, if few tortoises disperse from nearby small or declining populations (Adler and Nuernberger, 1994). Unoccupied patches present a special problem if the source of the decline is unknown because evidence is lacking to indicate whether the decline was due to temporary conditions for the occupants or if the site can no longer sustain tortoises. Obtaining better information about habitat quality requirements may resolve some of this uncertainty.

\section{Effectively Connecting Current Desert Tortoise Habitat to Recover Populations}

The patterns of population distribution and dynamics described earlier represent those of a "patchy" metapopulation (Harrison, 1991). For species with this type of metapopulation dynamic to persist over the long term, connectivity between patches must be provided through contiguous viable habitat. The Mojave desert tortoise requires interconnected habitat across its range to sustain populations within and outside of TCAs over multiple generations (Tracy and others, 2004). Low-mobility species, such as the desert tortoise, are considered "corridor dwellers" that may spend their entire life within corridors (Beier and Loe, 1992). In effect, low mobility of the species means that interconnected local populations of tortoises must persist across the landscape to ensure overall species persistence (fig. $2 B$ ).

In contrast, passage species may move through corridors between protected areas in days or weeks, even at large spatial scales (Beier and Loe, 1992). Though individual desert tortoises can move many kilometers in one season (Berry, 1986; Edwards and others, 2004), this type of movement has been observed in large, open areas rather than a long (for example, tens of kilometers), narrow strip of habitat a few meters - or even a few hundred meters - wide. Tortoises may traverse short culverts and thereby navigate the otherwise absolute barrier of a fenced road (Boarman and others, 1998) or may occupy narrow mountain passes (Dutcher and others, 2020b; Hromada and others, 2020), but tortoise movement patterns do not lead us to expect that a tortoise in one TCA would traverse a long narrow strip of preserved desert vegetation to another TCA many kilometers distant in its lifetime. For all these reasons, habitat linkages among TCAs must be wide enough to sustain multiple home ranges or local clusters of resident tortoises (Beier and others, 2008; Morafka, 1994), while accounting for edge effects, in order to sustain regional tortoise populations.

\section{Recent Research Relevant to Desert Tortoise Habitat and Connectivity}

A variety of spatial habitat models have been developed for the management of desert tortoise habitat, including models describing habitat suitability, levels of development within modeled habitat, landscape genetics, tortoise habitat linkages, and connectivity (appendix 1; figs. 1.1-1.4). These models have been used for project-proponent and regulatory planning, establishing survey requirements, evaluating reports for project compliance, and as base inputs for subsequent spatial models. Furthermore, many of the natural resource layers developed for these models (for example, soil texture layer by Nowicki and others, 2019; wash layers by Gray and others, 2019) have been applied to understand habitats for other species of management concern across the southwestern United States (for example, Mohave Ground Squirrel by Inman and others, 2013; multiple species and energy development by Vandergast and others, 2013). 
Spatial models that focus on habitat connectivity that are in development were presented at the annual symposium of the Desert Tortoise Council in February 2020 (https://deserttortoise.org/wp-content/uploads/ ABSTRACTS_2020-DTC-FINAL-Feb72020.pdf), and included syntheses of habitat status (Nussear and others, 2020), genetic responses to landscape disturbances (Dutcher and others, 2020a), desert tortoise movements (Hromada and others, 2020), demographics (Shoemaker and others, 2020), and alternative future habitat scenarios (Bassett and others, 2020). The development of these models is ongoing and dynamic. For example, three of the 'working' models have been published since the presentation in February (Dutcher and others, 2020b; Carter and others, 2020a; Hromada and others, 2020). In particular, these studies reinforced evidence of reduced movements and gene flow across linear barriers (highways and railroads), while reporting movements and gene flow across mountain passes (Dutcher and others, 2020b), and documented limited tortoise observations in areas with greater than 5-percent surface disturbance per $\mathrm{km}^{2}$ (fig. 3; Carter and others, 2020a). For these models, surface disturbance was derived for nationally available datasets, and does not necessarily include temporary disturbance.

Several additional models are still in development but can be accessed as they become ready for distribution. Available data and modelling, along with the models still in development, will further inform management agencies seeking to address connectivity issues for the Mojave desert tortoise.

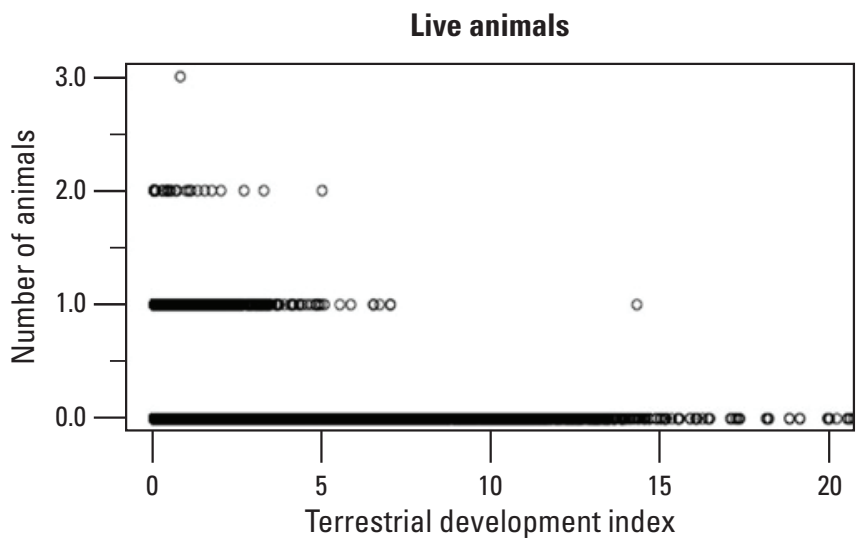

Figure 3. Observations of live Mojave desert tortoises from the U.S. Fish and Wildlife Service range-wide monitoring program relative to the proportion of development in the surrounding landscape within 1 kilometer $(\mathrm{km})$ of the observation location (Terrestrial Development Index). A development index value of 5 indicates that 5 percent of the area within $1 \mathrm{~km}$ of that location has been altered by development. Adapted from Carter and others (2020a).

\section{Management Implications}

Maintaining an ecological network (recovery network) for the Mojave desert tortoise, with a system of core habitats (TCAs) connected by linkages (Hilty and others, 2020), is necessary to support demographically viable populations and long-term gene flow within and between TCAs. There are three points for wildlife and land-management agencies to consider when making decisions that could affect connectivity of Mojave desert tortoise populations (for example, in updating actions in resource management plans or amendments that could help maintain or restore functional connectivity in light of the latest information).

\section{(1) Management of All Desert Tortoise Habitat for Persistence and Connectivity}

Desert tortoise populations continue to decline within most TCAs (Allison and McLuckie, 2018), and it is unlikely that trends are better in populations outside protected areas. Fragmentation exacerbates negative trends by increasing the probability that isolated populations will suffer irreversible declines due to stochastic (unpredictable) effects acting on their smaller local abundances, especially when combined with multiple external threats within the population fragments. Enhanced threat reduction to reverse declines within TCAs and maintained occupied habitat in the surrounding matrix would help reduce the variability in population growth rates and improve the resilience of protected populations, while implementing efforts to improve connectivity.

Each TCA has unique strengths and weaknesses regarding its ability to support minimum sustainable populations based on areal extent, and its ability to support population increases based on landscape connection with adjacent populations. Considering how proposed projects (inside or outside of TCAs) affect connectivity and the ability of TCAs to support at least 5,000 (the numerical goal for each TCA) adult tortoises could help managers maintain the resilience of TCAs to population declines. The same project in an alternative location may have very different impacts on local or regional connectivity. For example, within the habitat matrix surrounding TCAs, narrowly delineated corridors may not allow for natural population dynamics if they do not accommodate overlapping home ranges along most of their widths so that tortoises reside, grow, find mates, and produce offspring that can replace older tortoises (Beier and Loe, 1992; Beier, 2018). In addition, most habitat outside TCAs may receive more surface disturbance than habitat within TCAs (Carter and others, 2020a). Therefore, managing the entire remaining matrix of desert tortoise habitat for permeability may be better than delineating fixed corridors (Beier, 2018; Gray and others, 2019). These concepts apply, especially given uncertainty about long-term condition of habitat within and outside of TCAs under a changing climate. 
Ultimately, questions such as "What are the critical linkages that need to be protected?" may be better framed as "How can we manage the remaining habitat matrix in ways that sustain ecological processes and habitat suitability for special status species. " Land-management decisions made in the context of the latter question could be more conducive to maintenance of a functional ecological network and the recovery of the Mojave desert tortoise.

\section{(2) Limitations on Landscape-level Disturbance Across Habitat Managed for the Desert Tortoise}

Clearly delineating habitat linkages and differentiating them from non-delineated areas by the uses that are permitted or prohibited within them by specific management guidelines can help achieve functional connectivity. Such guidelines would be most effective if they considered and accounted for all surface disturbances (for example, temporary disturbances such as fiberoptic lines or off-highway vehicle routes, right-of-ways, utility-scale solar development, urbanization) to the extent possible. A weighted framework that varies with the permanence or severity of the disturbance and can be additive to quantify cumulative effects may be useful. For example, minor roads can alter tortoise movements independently of other features (Hromada and others, 2020; Peaden and others, 2017), but if the isolated dirt road is accompanied by a powerline that encourages raven predation (Xiong, 2020), the two features together may be additive. Ignoring minor or temporary disturbance on the landscape could result in a cumulatively large impact that is not explicitly acknowledged (Goble, 2009). Therefore, a commitment to understanding and quantifying all surface disturbance on a given landscape is needed.

a. In California, the Bureau of Land Management established 0.1-1.0-percent new surface-disturbance caps for TCAs and mapped linkages that address the issues described in the "(1) Management of All Desert Tortoise Habitat for Persistence and Connectivity" section (fig. 4; table 1; U.S. Bureau of Land Management, 2016).

b. Nevada, Utah, and Arizona currently do not have surface-disturbance limits. Limits comparable to those in the DRECP would be 0.5 percent within TCAs and 1 percent within the linkages modeled by Averill-Murray and others (2013). Limits in some areas of California within the DRECP, such as Ivanpah Valley, are more restrictive at 0.1 percent (fig. 4; table 1). Continuity across the state line in Nevada could be achieved with comparable limits in the adjacent portion of Ivanpah Valley, as well as the Greater Trout Canyon translocation area and the Stump Springs Regional Augmentation Site (fig. 5). These more restrictive limits help protect remaining habitat in the major interstate connectivity pathway through Ivanpah Valley (Hagerty and others, 2011) and focal areas of population augmentation that provide additional population connectivity along the western flank of the Spring Mountains.

c. In a recent study that analyzed 13 years of desert tortoise monitoring data, nearly all desert tortoise observations were at sites in which 5 percent or less of the surrounding landscape within $1 \mathrm{~km}$ was disturbed (Carter and others, 2020a). To help maintain tortoise inhabitance and permeability across all other non-conservation-designated tortoise habitat, all surface disturbance could be limited to less than 5-percent development per square kilometer because the 5-percent threshold for development is the point at which tortoise occupation drops precipitously (Carter and others, 2020a; fig. 3). However, it is important to note that 5 percent may not maintain population sizes needed for demographic or functional connectivity; therefore, ideally, development thresholds should be lower. Lower development thresholds would be particularly useful in areas within the upper 5 th percentile of connectivity values modeled by Gray and others (2019; fig. 1.3; fig. 5).

However, although individual desert tortoises were observed at development levels up to 5 percent, we do not know the fitness or reproductive characteristics of these individuals. This level of development also may not allow for long-term persistence of healthy populations that are of adequate size needed for demographic or functional connectivity; therefore, ideally development should be lower. This would be particularly useful in areas within the upper 5 th percentile of connectivity values modeled by Gray and others (2019).

d. Reducing ancillary threats in places where connectivity is restricted to narrow strips of habitat, for example, narrow mountain passes or vegetated strips between solar development, could enhance the functionality of these vulnerable linkages. In such areas, maintaining multiple, redundant linkages could further enhance overall connectivity. Attention to the spatial configuration of allowed disturbances also would help ensure that any existing bottlenecks to connectivity are not severed. 


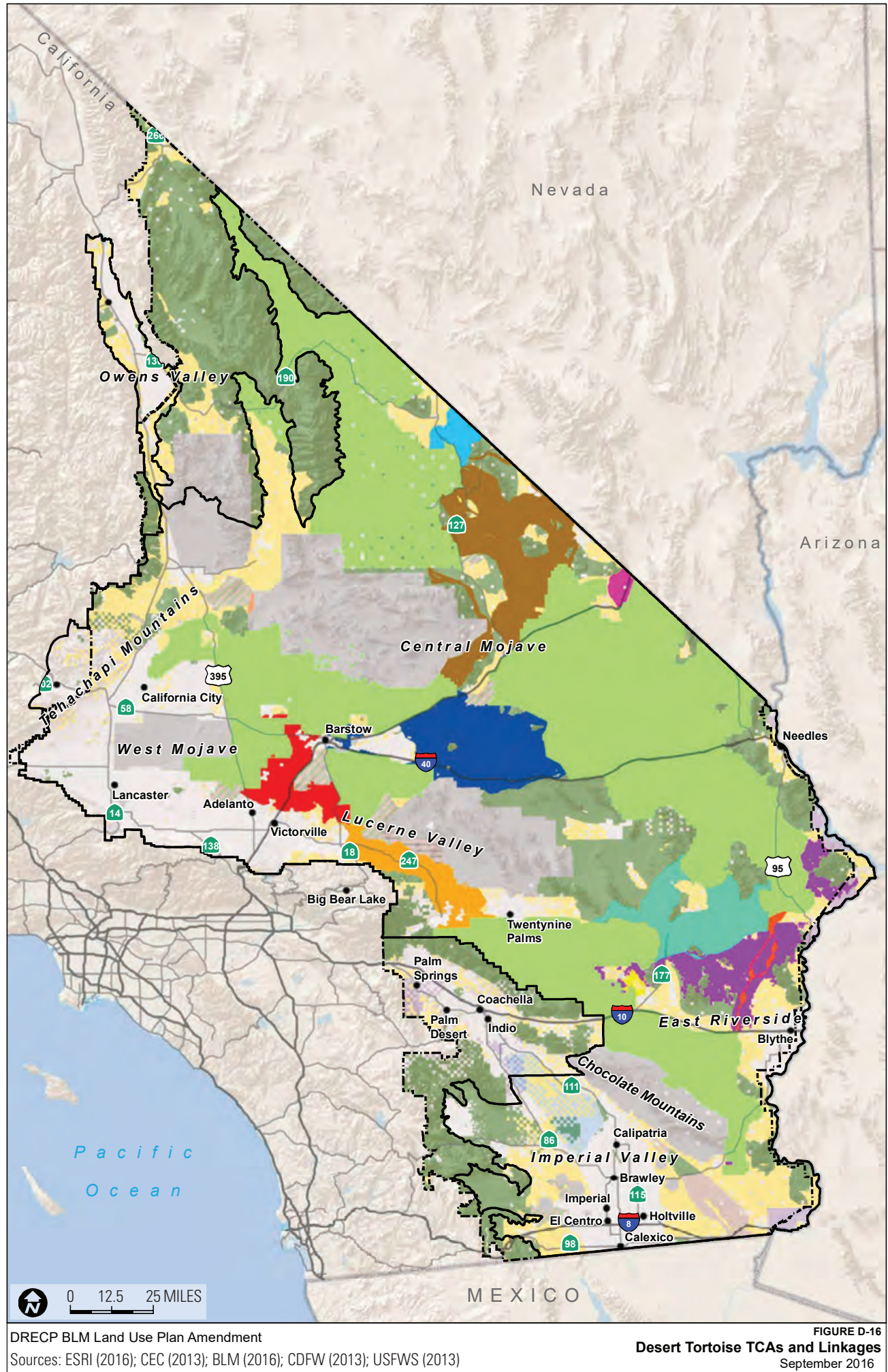

\section{EXPLANATION}

Biological goals and objectives Names

Tortoise conservation areas

Chemehuevi to Chuckwalla linkage

DVNP to Nevada test site linkage

Fremont-Kramer to Ord-Rodman linkage

Ivanpah Valley linkage

JTNP and Pinto Mountains to Chemehuevi linkage

Ord-Rodman to Joshua Tree National Park linkage

Ord-Rodman to Superior-Cronese to Mojave National Preserve

Pinto Wash linkage

Superior-Cronese to MNP to Shadow Valley to DVNP

High priority Colorado Desert habitat

Base layers

Legislatively and legally protected areas

Military expansion mitigation lands

Military

Open OHV areas -Imperial sand dunes

Open OHV areas

Johnson Valley OHV shared use area

Tribal lands

United States Bureau of Land Management

\section{NDAA China Lake} expansion

; CDCA plan boundary

DRECP plan area boundary

Figure 4. Desert tortoise conservation areas (TCAs) and linkages in the California Desert Renewable Energy Conservation Plan (U.S. Bureau of Land Management, 2016). Tortoise conservation areas are labeled according to table 1. 
Table 1. Surface-disturbance caps in desert tortoise conservation areas and linkages in the California Desert Renewable Energy Conservation Plan (U.S. Bureau of Land Management, 2016).

[ACEC, Area of Critical Environmental Concern; CHU, critical habitat unit]

\begin{tabular}{lc}
\hline \multicolumn{1}{c}{ Location } & $\begin{array}{c}\text { Disturbance cap } \\
\text { (percentage) }\end{array}$ \\
\hline \multicolumn{1}{c}{ T. Desert Tortoise Research Natural Area } & \\
2. Fremont-Kramer ACEC and CHU & 0.1 \\
3. Superior-Cronese ACEC and CHU & 0.5 \\
4. Ord-Rodman ACEC and CHU & 0.5 \\
5. Pinto Mountains ACEC and CHU & 0.5 \\
6. Chuckwalla ACEC and CHU & 0.5 \\
7. Chemehuevi Desert ACEC and CHU & 0.5 \\
8. Piute Valley ACEC and CHU & 0.5 \\
9. Shadow Valley ACEC & 0.5 \\
10. Ivanpah Valley ACEC (includes critical habitat on Bureau of Land Management land) & 0.5 \\
\hline \multicolumn{1}{c}{ Desert tortoise linkages (see legend in fig. 4) } & 0.1 \\
\hline Ord-Rodman to Superior-Cronese to Mojave National Preserve & \\
Superior-Cronese to Mojave National Preserve to Shadow Valley to Death Valley National Park & 1 \\
Joshua Tree National Park and Pinto Mountains to Chemehuevi & 1 \\
Death Valley National Park to Nevada National Security Site & 1 \\
Ivanpah Valley & 1 \\
Chemehuevi to Chuckwalla & 0.1 \\
Pinto Wash & 0.1 \\
Ord-Rodman to Joshua Tree National Park & 0.1 \\
Fremont-Kramer to Ord-Rodman & 0.5 \\
High-value Colorado Desert Habitat & 0.5 \\
\hline
\end{tabular}




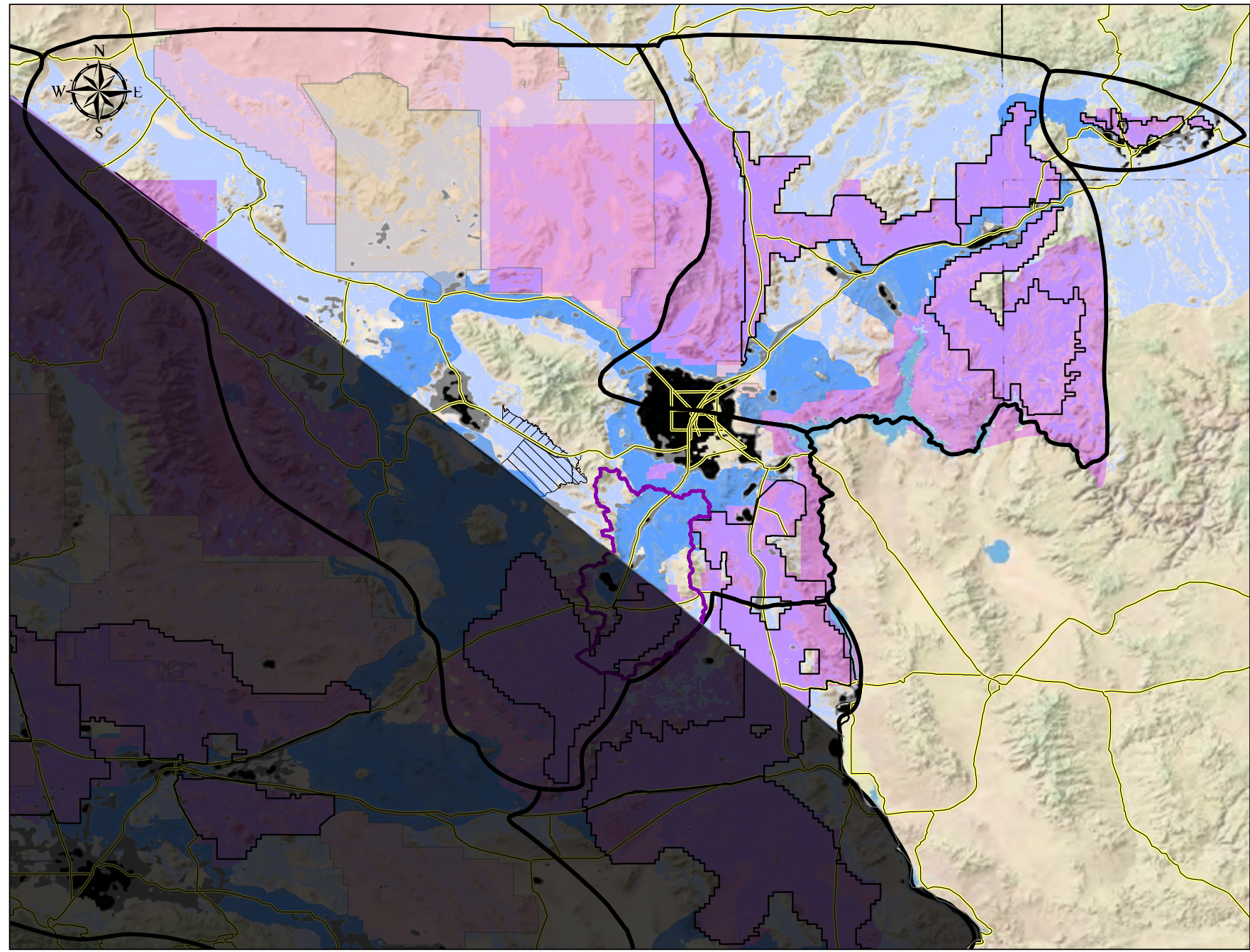

Image source: National Geographic Society. Copyright:@ 2013 National Geographic Society, i-cubed.

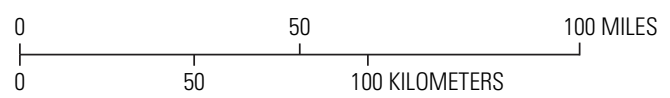

EXPLANATION

$\square$ Recovery units
$\square$ Critical habitat
Tortoise conservation areas
USFWS linkage model
$\square 7$ Trout Canyon Translocation area
$\square \nabla$ Stump Springs Augmentation Site
$\square$ Department of Defense
$\square$ Nevada National Security Site

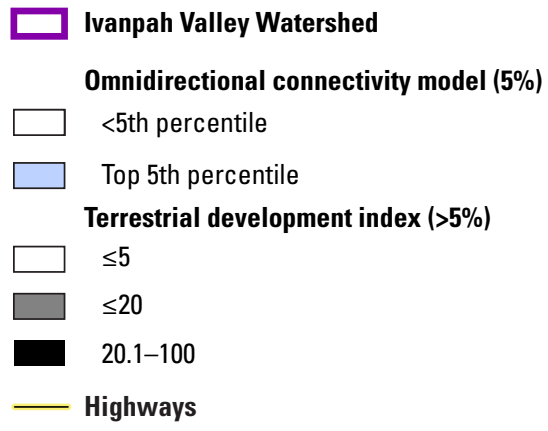

Figure 5. Tortoise conservation areas, linkages, and other habitat managed for desert tortoise population connectivity in Nevada, Utah, and Arizona. 


\section{(3) Minimization of Mortality from Roads and Maximization of Passage Under Roads}

Roads pose a significant threat to the long-term persistence of local tortoise populations, and roads of high traffic volume lead to severe population declines (Peaden, 2017), which ultimately fragments populations farther away from the roads. Three points pertain to reducing direct mortality of tortoises on the many paved roads that cross desert tortoise habitat and maintaining a minimal level of permeability across these roads.

a. Tortoise-exclusion fencing tied into culverts, underpasses or overpasses, or other passages below roads in desert tortoise habitat, would limit vehicular mortality of tortoises and would provide opportunities for movement across the roads (Boarman and others, 1997). Installation of shade structures on the habitat side of fences installed in areas with narrow population-depletion zones would limit overheating of tortoises that may pace the fence (Peaden and others, 2017).

b. Passages below highways could be maintained or retrofitted to ensure safe tortoise access, for example, by filling eroded drop-offs or by modifying erosion-control features, such as rip-rap, to make them safer and more passable for tortoises. Wildlife management agencies could work with transportation departments to develop construction standards that are consistent with hydrologic/erosion management goals, which would also maximize the potential for tortoise survival and passage and make the standards widely available. The process would be most effective if the status of passages was regularly monitored and built into management plans.

c. Healthy tortoise populations along fenced highways could be supported by ensuring that land inside tortoise-exclusion fences is not so degraded that it leads to degradation of tortoise habitat outside the exclusion areas. As one example, invasive plants inside road rights of way could be mown or treated with herbicide to limit their spread into adjacent tortoise habitat and to minimize the risk of these plants carrying wildfires into adjacent habitat.

\section{(4) Adaptation of Management Based on New Information}

The models described herein have already been useful for informing management of tortoise habitat to support population recovery and connectivity. Future research will continue to build upon and refine these models and develop new ones. New models could consider landscape levels of development and be constructed such that they share common foundations to support future synthesis efforts. If model development was undertaken in partnership with entities that are responsible for management of desert tortoise habitat, it would facilitate incorporation of current and future modeling results into their land management decisions (Carter and others, 2020b). There are specific topics that could be clarified with further evaluation:

a. The effects of climate change on desert tortoise habitat, distribution, and population connectivity (Nussear and others, 2020; Shoemaker and others, 2020);

b. The effects of large-scale fires, especially within repeatedly burned habitat, on desert tortoise distribution and population connectivity;

c. The ability of solar energy facilities or similar developments to support tortoise movement and presence by leaving washes intact, leaving native vegetation intact whenever possible, or if not possible, mowing the site to allow vegetation to re-sprout, managing weeds, and allowing tortoises to occupy the sites; and

d. The design and frequency of underpasses necessary to maintain functional demographic and genetic connectivity across linear features such as highways.

\section{Summary}

This report summarizes the underlying concepts and importance of landscape connectivity for Mojave desert tortoise populations by reviewing current information on connectivity and providing information to managers for maintaining or enhancing desert tortoise population connectivity as they consider future proposals for development and management actions. 


\section{References Cited}

Adler, F.R., and Nuernberger, B., 1994, Persistence in patchy irregular landscapes: Theoretical Population Biology, v. 45, no. 1, p. 41-75, https://doi.org/10.1006/tpbi.1994.1003.

Allison, L.J., and McLuckie, A.M., 2018, Population trends in Mojave desert tortoises (Gopherus agassizii): Herpetological Conservation and Biology, v. 13, no. 2, p. 433-452.

Ament, R., Callahan, R., McClure, M.L., Reuling, M., and Tabor, G., 2014, Wildlife connectivity-Fundamentals for conservation action: Bozeman, Mont., Center for Large Landscape Conservation.

Averill-Murray, R.C., Darst, C.R., Strout, N., and Wong, M., 2013, Conserving population linkages for the Mojave Desert tortoise (Gopherus agassizii): Herpetological Conservation and Biology, v. 8, no. 1, p. 1-15.

Bassett, S.D., Friend, D.A., Wright, S.A., Nussear, K.E., Esque, T.C., Boyle, D.P., and Heaton, J.S., 2020, Land use futures for the Mojave Desert, USA-Implications for the Mojave Desert Tortoise: Las Vegas, Nev., 45th Annual Symposium of the Desert Tortoise Council, February 22, 2020, p. 5-6.

Beier, P., 2018, A rule of thumb for widths of conservation corridors: Conservation Biology, v. 33, no. 4, p. 976-978, https://doi.org/10.1111/cobi.13256.

Beier, P., and Loe, S., 1992, A checklist for evaluating impacts to wildlife movement corridors: Wildlife Society Bulletin, v. 20 , no. 4, p. 434-440.

Beier, P., Majka, D.R., and Spencer, W.D., 2008, Forks in the road-Choices in procedures for designing wildland linkages: Conservation Biology, v. 22, no. 4, p. 836-851, https://doi.org/10.1111/j.1523-1739.2008.00942.x.

Berry, K.H., 1986, Desert tortoise (Gopherus agassizii) relocation-Implications of social behavior and movements: Herpetologica, v. 42, p. 113-125.

Boarman, W.I., and Sazaki, M., 2006, A highway’s road-effect zone for desert tortoises (Gopherus agassizii): Journal of Arid Environments, v. 65, no. 1, p. 94-101, https://doi.org/10.1016/j.jaridenv.2005.06.020.

Boarman, W.I., Sazaki, M., and Jennings, W.B., 1997, The effect of roads, barrier fences, and culverts on desert tortoise populations in California, USA, in Abbema, J.V., ed., Proceedings - Conservation, restoration, and management of tortoises and turtles-An International Conference: State University of New York, Purchase, N.Y., New York Turtle and Tortoise Society, p. 54-58.
Boarman, W.I., Beigel, M.L., Goodlett, G.C., and Sazaki, M., 1998, A passive integrated transponder system for tracking animal movements: Wildlife Society Bulletin, v. 26, p. 886-891.

Brown, J.H., and Kodric-Brown, A., 1977, Turnover rates in insular biogeography-Effect of immigration on extinction: Ecology, v. 58, no. 2, p. 445-449, https://doi.org/10.2307/1935620.

Carter, S.K., Nussear, K.E., Esque, T.C., Leinwand, I.I.F., Masters, E., Inman, R.D., Carr, N.B., and Allison, L.J., 2020a, Quantifying development to inform management of Mojave and Sonoran desert tortoise habitat in the American southwest: Endangered Species Research, v. 42, p. 167-184, https://doi.org/10.3354/esr01045.

Carter, S.K., Pilliod, D.S., Haby, T., Prentice, K.L., Aldridge, C.L., Anderson, P.J., Bowen, Z.H., Bradford, J.B., Cushman, S.A., DeVivo, J.C., Duniway, M.C., Hathaway, R.S., Nelson, L., Schultz, C.A., Schuster, R.M., Trammell, E.J., and Weltzin, J.F., 2020b, Bridging the research-management gap_Landscape science in practice on public lands in the western United States: Landscape Ecology, v. 35, no. 3, p. 545-560, https://doi.org/10.1007/s10980-020-00970-5.

Dutcher, K.E., Vandergast, A.G., Esque, T.E., Matocq, M.D., Heaton, J.S., and Nussear, K.E., 2020a, Connecting the plots-Anthropogenic disturbance and Mojave Desert tortoise genetic connectivity: Presented at a Special Session on Connectivity and the Desert Tortoise, Las Vegas, Nev., 45th Annual Symposium of the Desert Tortoise Council, February 22, 2020.

Dutcher, K.E., Vandergast, A.G., Esque, T.C., Mitelberg, A., Matocq, M.D., Heaton, J.S., and Nussear, K.E., 2020b, Genes in space-What Mojave desert tortoise genetics can tell us about landscape connectivity: Conservation Genetics, v. 21, no. 2, p. 289-303, https://doi.org/10.1007/s10592-020-01251-z.

Edwards, T., Stitt, E.W., Schwalbe, C.R., and Swann, D.E., 2004, Gopherus agassizii (desert tortoise) movement: Herpetological Review, v. 35, p. 381-382.

Emblidge, P.G., Nussear, K.E., Esque, T.C., Aiello, C.M., and Walde, A.D., 2015, Severe mortality of a population of threatened desert tortoises - The American badger as a novel predator: Endangered Species Research, v. 28, no. 2, p. 109-116, https://doi.org/10.3354/esr00680.

Environmental Law Institute, 2003, Conservation thresholds for land use planners: Washington, D.C., Environmental Law Institute. 
Esque, T.C., Nussear, K.E., Drake, K.K., Walde, A.D., Berry, K.H., Averill-Murray, R.C., Woodman, A.P., Boarman, W.I., Medica, P.A., Mack, J., and Heaton, J.S., 2010, Effects of subsidized predators, resource variability, and human population density on desert tortoise populations in the Mojave Desert, USA: Endangered Species Research, v. 12, no. 2, p. 167-177, https://doi.org/10.3354/esr00298.

Fahrig, L., 2002, Effect of habitat fragmentation on the extinction threshold-A synthesis: Ecological Applications, v. 12 , no. 2 , p. $346-353$, https://doi.org/10.1890/10510761(2002)012[0346:EOHFOT]2.0.CO;2.

Fahrig, L., and Merriam, G., 1994, Conservation of fragmented populations: Conservation Biology, v. 8, no. 1, p. 50-59, https://doi.org/10.1046/j.15231739.1994.08010050.x.

Frankham, R., 2006, Genetics and landscape connectivity, in Crooks, K.R., and Sanjayan, M., eds., Connectivity conservation: Cambridge, U.K., Cambridge University Press, p. 72-96, https://doi.org/10.1017/CBO9780511754821.005.

Germano, D.J., and Joyner, M.A., 1988, Changes in a desert tortoise (Gopherus agassizii) population after a period of high mortality, in Szaro, R.C., Severson, K.E., and Patton, D.R., Management of amphibians, reptiles, and small mammals in North America-Proceedings of the symposium: Fort Collins, Colorado, U.S. Department of Agriculture, Forest Service General Technical Report RM-166, p. 190-198.

Germano, D.J., Bury, R.B., Esque, T.C., Fritts, T.H., and Medica, P.A., 1994, Range and habitats of the desert tortoise, in Bury, R.B., and Germano, D.J., eds., Biology of North American tortoises, national biological survey v. 13: Washington, D.C., Fish and Wildlife Research, p. 73-84.

Goble, D.D., 2009, The endangered species act-What we talk about when we talk about recovery: Natural Resources Journal, v. 49, p. 1-44.

Gray, M.E., Dickson, B.G., Nussear, K.E., Esque, T.C., and Chang, T., 2019, A range-wide model of contemporary, omnidirectional connectivity for the threatened Mojave desert tortoise: Ecosphere, v. 10, no. 9, 16 p., https://doi.org/10.1002/ecs2.2847.

Hagerty, B.E., and Tracy, C.R., 2010, Defining population structure for the Mojave desert tortoise: Conservation Genetics, v. 11, no. 5, p. 1795-1807, https://doi.org/10.1007/s10592-010-0073-0.

Hagerty, B.E., Nussear, K.E., Esque, T.C., and Tracy, C.R., 2011, Making molehills out of mountainsLandscape genetics of the Mojave desert tortoise: Landscape Ecology, v. 26, no. 2, p. 267-280, https://doi.org/10.1007/s10980-010-9550-6.
Harrison, S., 1991, Local extinction in a metapopulation context-An empirical evaluation: Biological Journal of the Linnean Society. Linnean Society of London, v. 42, no. 1-2, p. 73-88, https://doi.org/10.1111/j.1095-8312.1991.tb00552.x.

Harrison, S., and Bruna, E., 1999, Habitat fragmentation and large-scale conservation-What do we know for sure?: Ecography, v. 22, no. 3, p. 225-232, https://doi.org/10.1111/j.1600-0587.1999.tb00496.x.

Hilty, J., Worboys, G.L., Keeley, A., Woodley, S., Lausche, B., Locke, H., Carr, M., Pulsford, I., Pittock, J., White, J.W., Theobald, D.M., Levine, J., Reuling, M., Watson, J.E.M., Ament, R., and Tabor, G.M., 2020, Guidelines for conserving connectivity through ecological networks and corridors-Best practice protected area guidelines series: Gland, Switzerland, International Union for Conservation of Nature, no. 30, 122 p.

Hoff, K.S., and Marlow, R.W., 2002, Impacts of vehicle road traffic on desert tortoise populations with consideration of conservation of tortoise habitat in southern Nevada: Chelonian Conservation and Biology, v. 4, p. 449-456.

Hromada, S.J., Esque, T.C., Vandergast, A.G., Dutcher, K.E., Mitchell, C.I., Gray, M.E., Chang, T., Dickson, B.G., and Nussear, K.E., 2020, Using movement to inform conservation corridor design for Mojave desert tortoise: Movement Ecology, v. 8, no. 38, p. 1-18, https://doi.org/10.1186/s40462-020-00224-8.

Hylander, K., and Ehrlén, J., 2013, The mechanisms causing extinction debts: Trends in Ecology \& Evolution, v. 28, no. 6, p. 341-346, https://doi.org/10.1016/j.tree.2013.01.010.

Inman, R.D., Nussear, K.E., Matocq, M., Dilts, T., Weisberg, P., Vandergast, A., and Esque, T.C., 2013, Is there room for all of us? Renewable energy and Xerospermophilus mohavensis: Endangered Species Research, v. 20, no. 1, p. 1-18, https://doi.org/10.3354/esr00487.

Krosby, M., Tewksbury, J., Haddad, N.M., and Hoekstra, J., 2010, Ecological connectivity for a changing climate: Conservation Biology, v. 24, no. 6, p. 1686-1689, https://doi.org/10.1111/j.1523-1739.2010.01585.x.

Kristan, W.B., III, and Boarman, W.I., 2003, Spatial pattern of risk of common raven predation on desert tortoises: Ecology, v. 84, no. 9, p. 2432-2443, https://doi.org/10.1890/02-0448.

Krzysik, A.J., 2002, A landscape sampling protocol for estimating distribution and density patterns of desert tortoises at multiple spatial scales: Chelonian Conservation and Biology, v. 4, p. 366-379. 
Kuo, C.H., and Janzen, F.J., 2004, Genetic effects of a persistent bottleneck on a natural population of ornate box turtles (Terrapene ornata):

Conservation Genetics, v. 5, no. 4, p. 425-437, https://doi.org/10.1023/B:COGE.0000041020.54140.45.

Kuussaari, M., Bommarco, R., Heikkinen, R.K., Helm, A., Krauss, J., Lindborg, R., Öckinger, E., Pärtel, M., Pino, J., Rodà, F., Stefanescu, C., Teder, T., Zobel, M., and Steffan-Dewenter, I., 2009, Extinction debt-A challenge for biodiversity conservation: Trends in Ecology \& Evolution, v. 24, no. 10, p. 564-571, https://doi.org/10.1016/j.tree.2009.04.011.

Lefkovitch, L.P., and Fahrig, L., 1985, Spatial characteristics of habitat patches and population survival: Ecological Modelling, v. 30, no. 3-4, p. 297-308, https://doi.org/10.1016/0304-3800(85)90072-9.

Longshore, K.M., Jaeger, J.R., and Sappington, J.M., 2003, Desert tortoise (Gopherus agassizii) survival at two eastern Mojave desert sites-Death by short-term drought?: Journal of Herpetology, v. 37, no. 1, p. 169-177, https://doi.org/ 10.1670/0022-1511(2003)037[0169:DTGASA]2.0.CO;2.

MacArthur, R.H., and Wilson, E.O., 1967, The theory of island biogeography: Princeton, New Jersey, Princeton University Press.

Meiklejohn, K., Ament, R., and Tabor, G., 2010, Habitat corridors \& landscape connectivity-Clarifying the terminology. Center of Large Landscape Conservation, $6 \mathrm{p}$.

Morafka, D.J., 1994, Neonates-Missing links in the life histories of North American tortoises, in Bury, R.B., and Germano, D.J., eds., Biology of North American tortoises: Washington, D.C., National Biological Survey, Fish and Wildlife Research, v. 13, p. 161-173.

Murphy, R.W., Berry, K.H., Edwards, T., and McLuckie, A.M., 2007, A genetic assessment of the recovery units for the Mojave population of the desert tortoise, Gopherus agassizii: Chelonian Conservation and Biology, v. 6, no. 2, p. 229-251, https://doi.org/10.2744/10718443(2007)6[229:AGAOTR]2.0.CO;2.

Nafus, M.G., Tuberville, T.D., Buhlmann, K.A., and Todd, B.D., 2013, Relative abundance and demographic structure of Agassiz's desert tortoise (Gopherus agassizii) along roads of varying size and traffic volume: Biological Conservation, v. 162, p. 100-106, https://doi.org/10.1016/j.biocon.2013.04.009.
National Fish, Wildlife, and Plants Climate Adaptation Partnership, 2012, National fish, wildlife and plants climate adaptation strategy: Association of Fish and Wildlife Agencies, Council on Environmental Quality, Great Lakes Indian Fish and Wildlife Commission, National Oceanic and Atmospheric Administration, and U.S. Fish and Wildlife Service. Washington, D.C., 112 p.

Nowicki, S.A., Inman, R.D., Esque, T.C., Nussear, K.E., and Edwards, C.S., 2019, Spatially consistent high-resolution land surface temperature mosaics for thermophysical mapping of the Mojave Desert: Sensors (Basel), v. 19, no. 12, 17 p., https://doi.org/10.3390/s19122669.

Nussear, K.E., Esque, T.C., Inman, R.D., Gass, L., Thomas, K.A., Wallace, C.S.A., Blainey, J.B., Miller, D.M., and Webb, R.H., 2009, Modeling habitat of the desert tortoise (Gopherus agassizii) in the Mojave and parts of the Sonoran deserts of California, Nevada, Utah, and Arizona: U.S. Geological Survey Open-File Report 2009-1102, 18 p., https://doi.org/10.3133/ofr20091102.

Nussear, K., Heaton, J., Bassett, S., Boyle, D., Matocq, M., Parandhaman, A., Friend, D., Wright, S., Dutcher, K., Hromada, S., Mitchell, C., Vandergast, A., and Esque, T., 2020, Progress toward understanding the impacts of land use and climate change on desert tortoise structural genetics and corridor functionality: Las Vegas, Nev., 45th Annual Symposium of the Desert Tortoise Council, February 22, 2020.

Ovaskainen, O., Sato, K., Bascompte, J., and Hanski, I., 2002, Metapopulation models for extinction threshold in spatially correlated landscapes: Journal of Theoretical Biology, v. 215, no. 1, p. 95-108, https://doi.org/10.1006/jtbi.2001.2502.

Peaden, J.M., 2017, Habitat use and behavior of Agassiz's desert tortoise (Gopherus agassizii)_Outpacing development to achieve long standing conservation goals for a federally threatened species: Davis, Calif., University of California, Davis, Ph.D. dissertation.

Peaden, J.M., Nowakowski, A.J., Tuberville, T.D., Buhlmann, K.A., and Todd, B.D., 2017, Effects of roads and roadside fencing on movements, space use, and carapace temperatures of a threatened tortoise: Biological Conservation, v. 214, p. 13-22, https://doi.org/10.1016/j.biocon.2017.07.022.

Peaden, J.M., Tuberville, T.D., Buhlmann, K.A., Nafus, M.G., and Todd, B.D., 2015, Delimiting road-effect zones for threatened species - Implications for mitigation fencing: Wildlife Research, v. 42, no. 8, p. 650-659, https://doi.org/10.1071/WR15082. 
Peterson, C.C., 1994, Different rates and causes of high mortality in two populations of the threatened desert tortoise Gopherus agassizii: Biological Conservation, v. 70, no. 2, p. 101-108, https://doi.org/10.1016/0006-3207(94)90277-1.

Radeloff, V.C., Stewart, S.I., Hawbaker, T.J., Gimmi, U., Pidgeon, A.M., Flather, C.H., Hammer, R.B., and Helmers, D.P., 2010, Housing growth in and near United States protected areas limits their conservation value: Proceedings of the National Academy of Sciences of the United States of America, v. 107, no. 2, p. 940-945, https://doi.org/10.1073/pnas.0911131107.

Rautsaw, R.M., Martin, S.A., Vincent, B.A., Lanctot, K., Bolt, M.R., Seigel, R.A., and Parkinson, C.L., 2018, Stopped dead in their tracks - The impact of railways on gopher tortoise (Gopherus polyphemus) movement and behavior: Copeia, v. 106, no. 1, p. 135-143, https://doi.org/10.1643/CE-17-635.

Shaffer, M.L., and Stein, B.A., 2000, Safeguarding our precious heritage, in Stein, B., Kutner, L.S., and Adams, J.S., eds., Precious heritage-The status of biodiversity in the United States: New York, Oxford University Press, p. 301-321, https://doi.org/10.1093/oso/9780195125191.003.0017.

Shoemaker, K.T., Walden, M., Hunter, E., Esque, T.C., and Nussear, K.E., 2020, Modeling critical habitat for Mojave desert tortoises in a non-stationary world: Las Vegas, Nev., 45 th Annual Symposium of the Desert Tortoise Council, February 22, 2020.
Tracy, C.R., Averill-Murray, R., Boarman, W.I., Delehanty, D., Heaton, J., McCoy, E., Morafka, D., Nussear, K., Hagerty, B., and Medica, P., 2004, Desert tortoise recovery plan assessment: Reno, Nev., Report to the U.S. Fish and Wildlife Service.

U.S. Bureau of Land Management, 2016, Desert renewable energy conservation plan-Record of decision for the land use plan amendment to the California desert conservation plan, Bishop resource management plan, and Bakersfield resource management plan: U.S. Bureau of Land Management, https:/eplanning.blm.gov/public_projects/ lup/66459/133460/163124/DRECP_BLM_LUPA_ROD.pdf.

U.S. Fish and Wildlife Service, 1994, Desert tortoise (Mojave population) recovery plan: Portland, Oregon, U.S. Fish and Wildlife Service.

U.S. Fish and Wildlife Service, 2011, Revised recovery plan for the Mojave population of the desert tortoise (Gopherus agassizii): Sacramento, Calif., U.S. Fish and Wildlife Service, Pacific Southwest Region.

U.S. Fish and Wildlife Service, 2016, USFWS Species status assessment framework-An integrated analytical framework for conservation, ver. 3.4 dated August 2016.

Vandergast, A.G., Inman, R.D., Barr, K.R., Nussear, K.E., Esque, T.C., Hathaway, S.A., Wood, D.A., Medica, P.A., Breinholt, J.W., Stephen, C.L., Gottscho, A.D., Marks, S.B., Jennings, W.B., and Fisher, R.N., 2013, Evolutionary hotspots in the Mojave Desert: Diversity (Basel), v. 5, no. 2, p. 293-319, https://doi.org/10.3390/d5020293.

Xiong, A.P., 2020, Spatial analysis of common raven monitoring and management data for desert tortoise critical habitat units in California: Reno, Nev., Master's thesis, University of Nevada, Reno, 69 p. 


\section{Appendix 1. Recent Desert Tortoise Habitat and Connectivity Models}

The figures provided in this appendix (figs. 1.1-1.4) were important in the development of guidance on the habitat connectivity needs of the Mojave desert tortoise for natural resource managers.

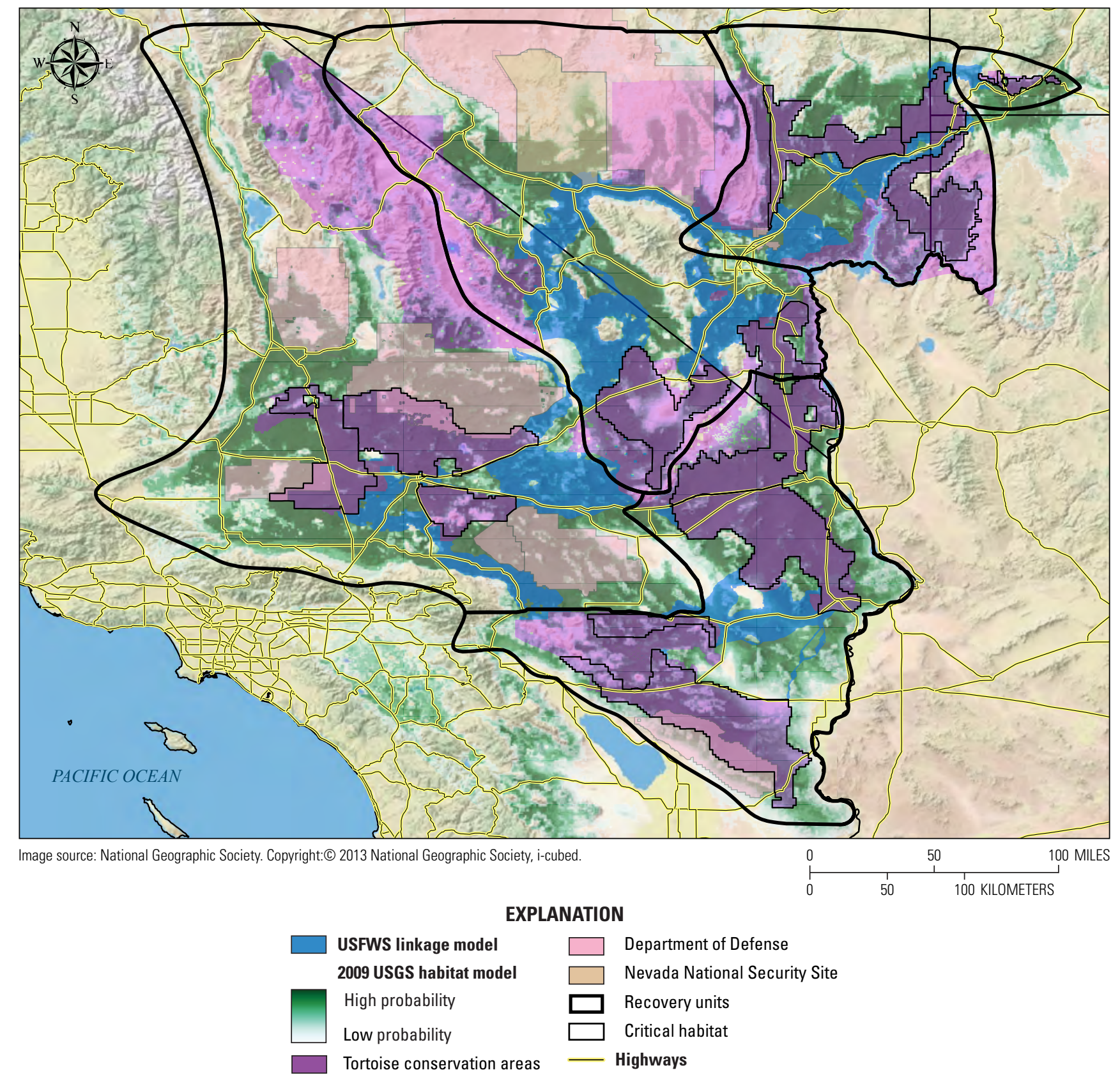

Figure 1.1. Range-wide Mojave desert tortoise habitat probability model (Nussear and others, 2009) overlain by the U.S. Fish and Wild life Service (USFWS) linkage model (Averill-Murray and others, 2013) that connects designated tortoise conservation areas. The color ramp from white to green represents the probability of tortoise presence from low to high, respectively. 


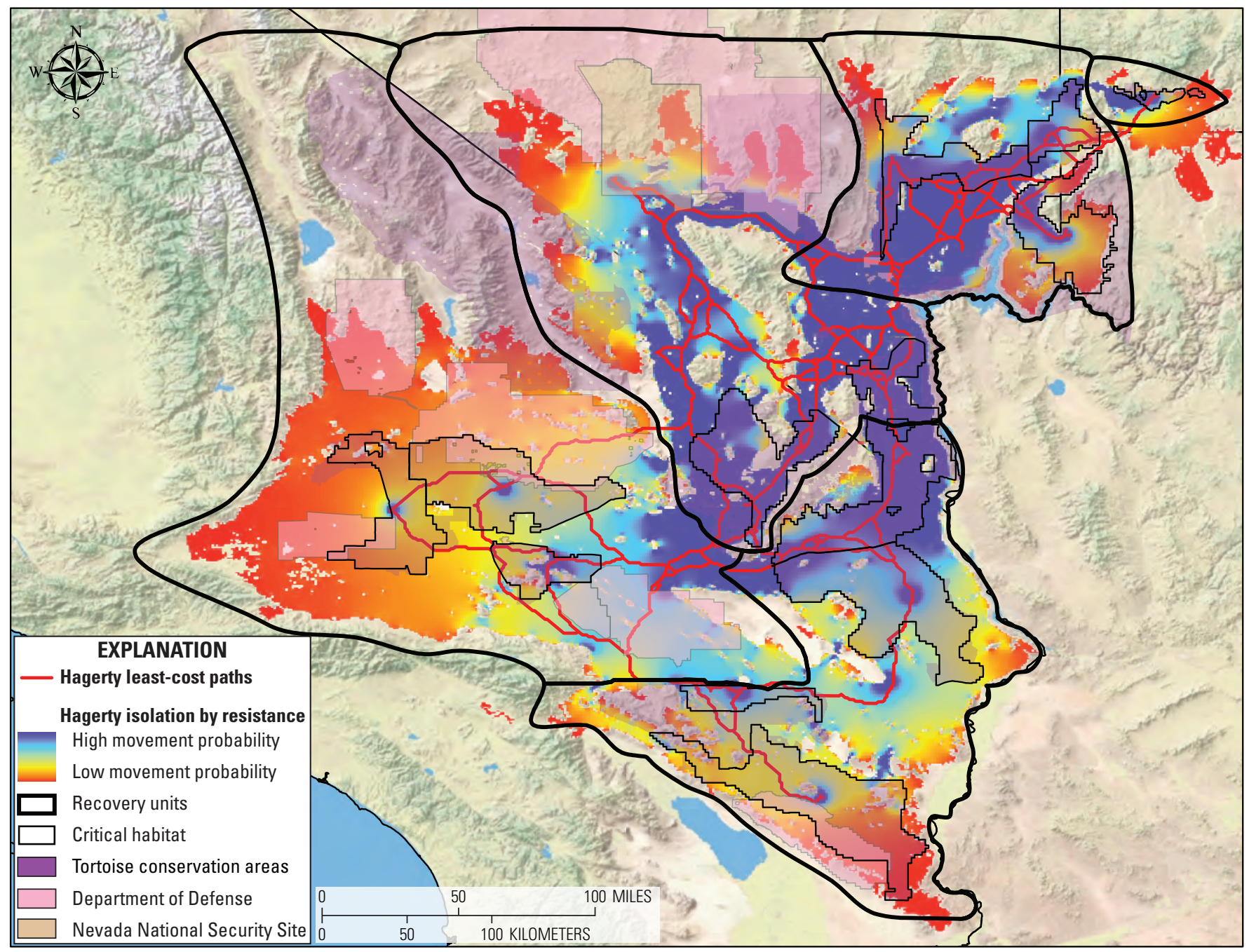

Image source: National Geographic Society. Copyright:@ 2013 National Geographic Society, i-cubed.

Figure 1.2. Mojave desert tortoise landscape genetics modeled by Hagerty and others (2011) showing least-cost paths between sampled population centroids overlying an isolation-by-resistance surface. 


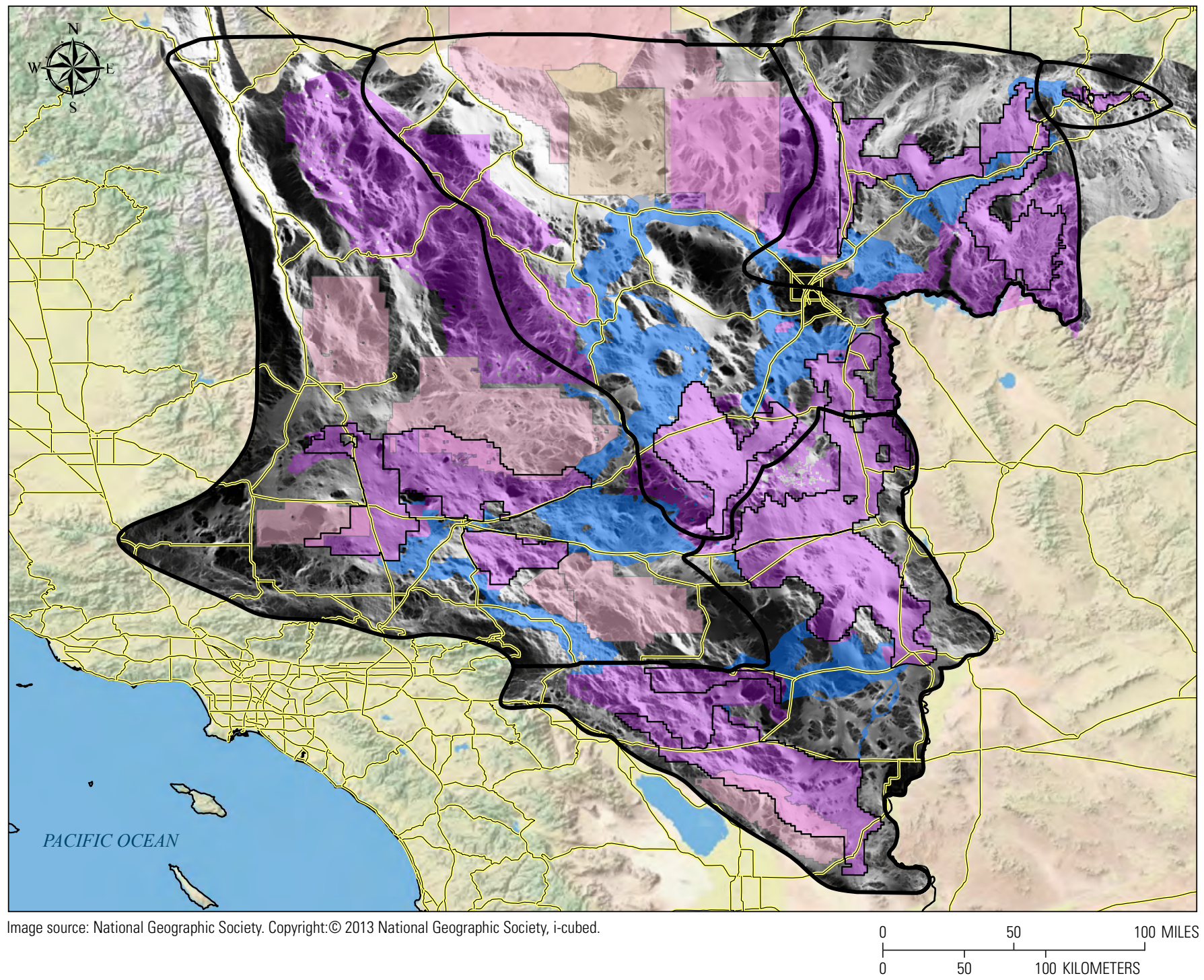

EXPLANATION

\begin{tabular}{lll}
$\begin{array}{ll}\text { Omnidirectional connectivity model } \\
\text { High connectivity }\end{array}$ & Department of Defense \\
Low connectivity & $\square$ Nevada National Security Site \\
\hline USFWS linkage model & $\square$ Critical habitat \\
\hline Tortoise conservation areas & - Highways
\end{tabular}

Figure 1.3. Range-wide omnidirectional connectivity model (Gray and others, 2019) for the Mojave desert tortoise overlain by the U.S. Fish and Wildlife Service (USFWS) linkage model (blue) that connects designated tortoise conservation areas (Averill-Murray and others, 2013). 


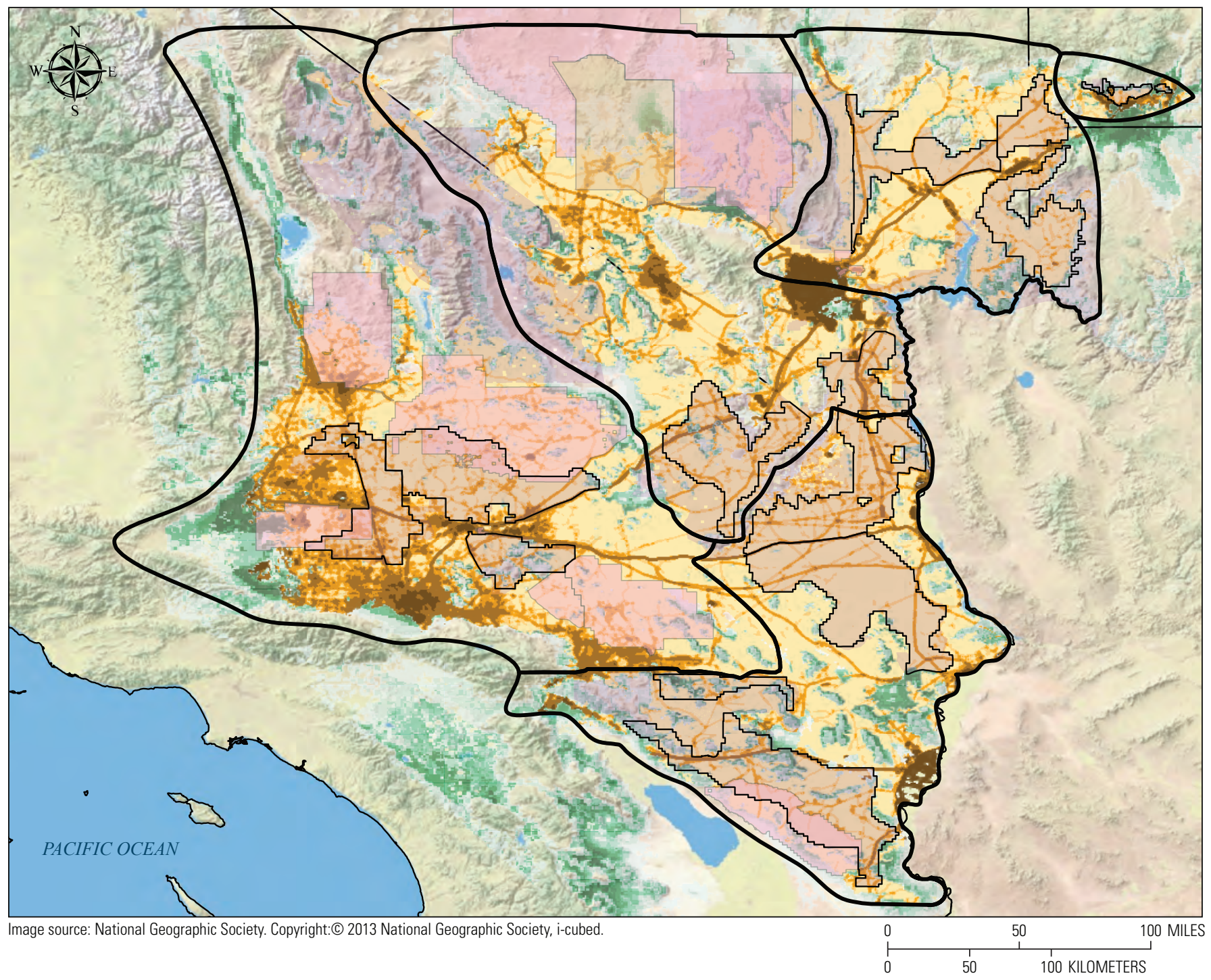

EXPLANATION

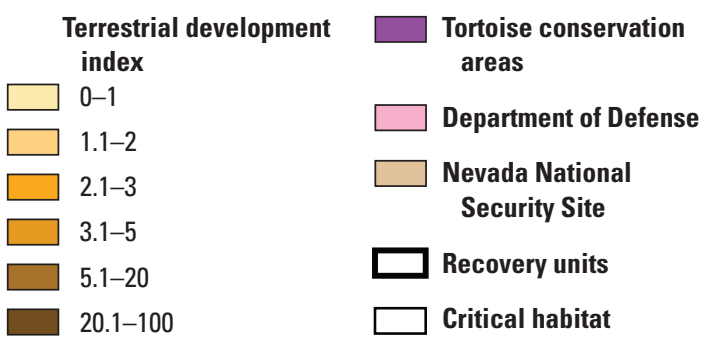

Figure 1.4. Terrestrial development index modeled by Carter and others (2020). 


\section{References Cited}

Averill-Murray, R.C., Darst, C.R., Strout, N., and Wong, M., 2013, Conserving population linkages for the Mojave Desert tortoise (Gopherus agassizii): Herpetological Conservation and Biology, v. 8, no. 1, p. 1-15.

Carter, S.K., Esque, T.C., Nussear, K.E., Leinwand, I.I.F., Masters, E., Inman, R.D., Carr, N.B., and Allison, L.J., 2020, Quantifying development to inform management of Mojave and Sonoran desert tortoise habitat in the American southwest: Endangered Species Research, v. 42, p. 167-184, https://doi.org/10.3354/esr01045.
Gray, M.E., Dickson, B.G., Nussear, K.E., Esque, T.C., and Chang, T., 2019, A range-wide model of contemporary, omnidirectional connectivity for the threatened Mojave desert tortoise: Ecosphere, v. 10, no. 9, 16 p., https://doi.org/10.1002/ecs2.2847.

Hagerty, B.E., and Tracy, C.R., 2010, Defining population structure for the Mojave desert tortoise: Conservation Genetics, v. 11, no. 5, p. 1795-1807, https://doi.org/ 10.1007/s10592-010-0073-0.

Nussear, K.E., Esque, T.C., Inman, R.D., Gass, L., Thomas, K.A., Wallace, C.S.A., Blainey, J.B., Miller, D.M., and Webb, R.H., 2009, Modeling habitat of the desert tortoise (Gopherus agassizii) in the Mojave and parts of the Sonoran deserts of California, Nevada, Utah, and Arizona: U.S. Geological Survey Open-file Report 2009-1102, 18 p., https://doi.org/10.3133/ofr20091102. 

For more information concerning the research in this report, contact the

Director, Western Ecological Research Center

U.S. Geological Survey

3020 State University Drive East

Sacramento, California 95819

https://www.usgs.gov/centers/werc

Publishing support provided by the U.S. Geological Survey

Science Publishing Network, Sacramento Publishing Service Center 


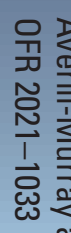

券

$\stackrel{\circ}{\Xi}$ 